Energy Techrology Division Energy Tochnology Division Energy Technology Division Energy Technology Division Finergy Trohology Division [Engrgy Technology Division Enerey technology Division Enercy Technology Division Energy technology Division Energy Techmology Division Energy Technology Division Eneroy Tochnology Division Energy Technology Division Energy Technolocy Division Energy Technology Division Energy Techndogy Diviston Encroy Tochnology Division Energy Technology Division Emoryy Tectmology Division Energy Technology Division Erorgy Tochndogy bivision Eneray Technology Dision Eneroy Techoology Division Energy Tochnology Dision Energy Techmology Divighom fnoryy Jechnology Division

\section{Weight Losses of Marble and Limestone Briquettes Exposed to Outdoor Environment in the Eastern United States}

Results of Exposure 1988-1992 by K. J. Reimann

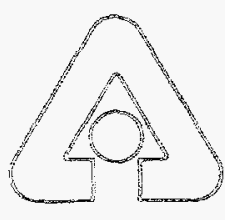

Argonne National Laboratory, Argonne, Illinois 60439 operated by The University of Chicago

for the United States Department of Energy under Contract W-31-109-Eng-38

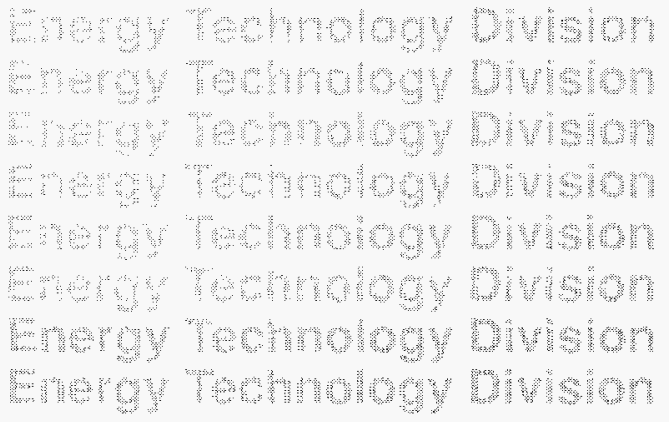


Argonne National Laboratory, with facilities in the states of Illinois and Idaho, is owned by the United States government, and operated by The University of Chicago under the provisions of a contract with the Department of Energy.

\section{DISCLAIMER}

This report was prepared as an account of work sponsored by an agency of the United States Government. Neither the United States Government nor any agency thereof, nor any of their employees, makes any warranty, express or implied, or assumes any legal liability or responsibility for the accuracy, completeness, or usefulness of any information, apparatus, product, or process disclosed, or represents that its use would not infringe privately owned rights. Reference herein to any specific commercial product, process, or service by trade name, trademark, manufacturer, or otherwise, does not necessarily constitute or imply its endorsement, recommendation, or favoring by the United States Government or any agency thereof. The views and opinions of authors expressed herein do not necessarily state or reflect those of the United States Government or any agency thereof.

Reproduced from the best available copy.

Available to DOE and DOE contractors from the

Office of Scientific and Technical Information

$$
\text { P.O. Box } 62
$$

Oak Ridge, TN 37831

Prices available from (423) 576-8401

Available to the public from the

National Technical Information Service

U.S. Department of Commerce

5285 Port Royal Road

Springfield, VA 22161 
Distribution

Category:

Energy Research

(UC-400)

ARGONNE NATIONAL LABORATORY

9700 South Cass Avenue, Argonne, Illinois 60439

ANL-95/22

\title{
WEIGHT LOSSES OF MARBLE AND LIMESTONE BRIgUETTES EXPOSED TO OUTDOOR ENVIRONMENT IN THE EASTERN UNITED STATES
}

RESULTS OF EXPOSURE 1988-1992

\author{
by \\ K. J. Reimann \\ Energy Technology Division \\ Instrumentation and NDE Section

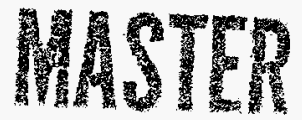 \\ April 1995 \\ Work sponsored by \\ U.S. NATIONAL PARK SERVICE
}

as part of the National Acid Precipitation Assessment Program 


\section{DISCLAIMER}

Portions of this document may be illegible in electronic image products. Images are produced from the best available original document. 


\section{Contents}

Abstract

1 Introduction

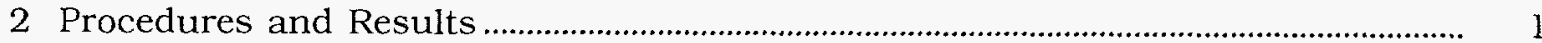

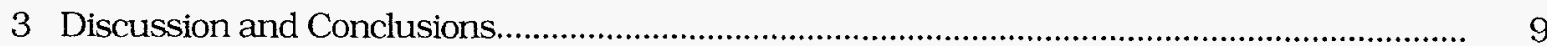

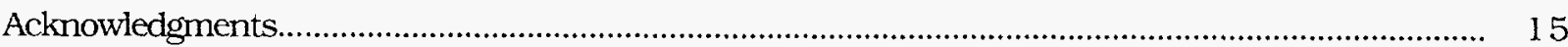

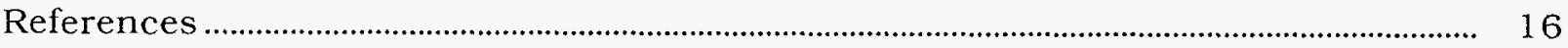

Appendix: Weight Losses from Individual Briquettes .......................................................... 17

\section{Figures}

1 Cumulative weight loss as a function of cumulative exposure time: (a) fresh marble and (b) fresh limestone

2 Cumulative weight loss of control briquettes as a function of cumulative elapsed time for (a) marble and (b) limestone

3 Cumulative weight loss of preexposed briquettes as a function of cumulative exposure time for (a) marble and (b) limestone

\section{Tables}

1 Dates of gravimetric specimen installation and removal at field exposure sites....

2 Incremental weight changes and associated recession of fresh marble briquettes for the period 1988-1992

3 Incremental weight changes and associated recession of fresh limestone briquettes for the period 1988-1992

4 Incremental weight changes and associated recession of preexposed marble briquettes for the period 1988-1992

5 Incremental weight changes and associated recession of preexposed limestone briquettes for the period 1988-1992

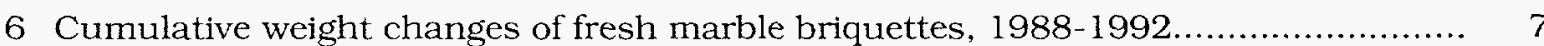

7 Cumulative weight changes of fresh limestone briquettes, 1988-1992 ................ 7

8 Cumulative weight changes of preexposed marble briquettes, $1988-1992 \ldots \ldots \ldots \ldots . . . \quad 8$

9 Cumulative weight changes of preexposed limestone briquettes, 1988-1992 ....... 8

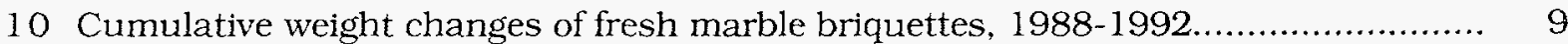

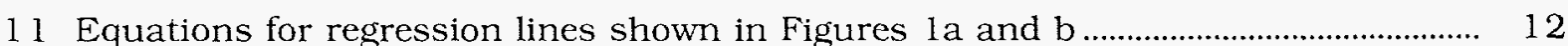

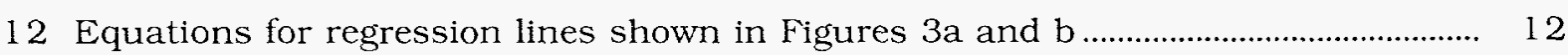

13 Average recession rates of exposed briquettes, by exposure site ............................... 14 
A.1 Weight changes in exposed and control briquettes: fresh stone, annuals, $1988-1989$

A.2 Weight changes in exposed and control briquettes: fresh stone, annuals, 1989-1990 and 1990-1992

A.3 Weight changes in exposed and control briquettes: fresh stone, quinquennials, 1984-1989.

A.4 Weight changes in exposed and control briquettes: fresh stone, quinquennials, 1989 runoff

A.5 Weight changes in exposed and control briquettes: preexposed stone, annuals, 1988-1989

A.6 Weight changes in exposed and control briquettes: preexposed stone, annuals, 1989-1990 and 1990-1992 


\title{
WEIGHT LOSSES OF MARBLE AND LIMESTONE BRIQUETTES \\ EXPOSED TO OUTDOOR ENVIRONMENT \\ IN THE EASTERN UNITED STATES
}

RESULTS OF EXPOSURE, 1988-1992

by

K. J. Reimann

\begin{abstract}
Monitoring continued on weight changes in marble and limestone briquettes exposed to the outdoor environment at sites in the eastern United States. This report presents data for the exposure period 1988-1992 and summarizes results for the entire period from 1984. Since 1989, only three exposure sites have remained active, but briquettes from preexposed material were added at those sites. A linear relationship was found between cumulative gravimetric losses and exposure period. These losses resulted in an average recession rate of 11 to $21 \mu \mathrm{m} / \mathrm{yr}$ for marble and 21 to $45 \mu \mathrm{m} / \mathrm{yr}$ for limestone. The recession rates are site-dependent and can be described with respect to rain depth and other atmospheric conditions, as evidenced by the very low rates at the Ohio site on the movable rack, dry regime. Weight monitoring is continuing in a planned 10-year program.
\end{abstract}

\section{INTRODUCTION}

Studies of the effects of acid precipitation and air pollution on the weathering of Shelburne marble and Salem limestone at test sites in the eastern United States are continuing under the sponsorship of the U.S. Department of Interior, National Park Service. Monitoring of weight changes of marble and limestone briquettes after exposure to the environment at the test sites is one of several tasks performed at Argonne National Laboratory (ANL).

The environmental exposure of stone briquettes began in May 1984 at test sites in Raleigh, NC; Chester, NJ; Newcomb, NY; Washington, DC; and in 1986 in Steubenville, $\mathrm{OH}^{1}$. The exposure sites are instrumented to record a wide range of environmental parameters.

Sets of gravimetry briquettes are installed in racks at each site ${ }^{1}$ for annual or multiyear exposure periods. Withdrawal, weighing, and reinstallation of gravimetric briquettes follows a strict protocol, 1 summarized in the description of experimental procedures in Refs. 2 and 3. Outdoor exposure of briquettes at the NJ site was discontinued in 1987, but the quinquennial briquettes were retrieved in 1989 and weighed. Similarly, exposure at the NC site was discontinued in 1989.

This report details the results obtained by weight measurements from 1988 to 1992 . All data from 1984 to 1992 were used to generate the graphs in order to assess trends of long-time exposure. Weight changes of individual briquettes are listed in the Appendix.

\section{PROCEDURES AND RESULTS}

Three briquettes of each stone type exposed at each active site, together with the site simulation samples, were retrieved according to schedule, dried, weighed, and returned to the exposure site for reinstallation. Included in the measurement procedure ${ }^{2}$ were three control samples that were kept at ANL. In 1989, three quinquennial briquettes of each 
stone type were retrieved and measured, together with the annual samples from the respective exposure sites (except $\mathrm{NJ}$ and $\mathrm{OH}$ ). At the $\mathrm{NJ}$ site, no annual samples were exposed after 1987. Quinquennial briquettes from $\mathrm{OH}$ were not due for retrieval in that year. In 1988, after installation of preexposed briquettes at $\mathrm{NC}, \mathrm{NY}, \mathrm{DC}$, and $\mathrm{OH}$, their retrieval and weight measurements were made to coincide with those of annual briquettes formed from fresh stone.

Some deviation in the retrieval schedule occurred in $\mathrm{OH}$ and $\mathrm{DC}$, mainly due to changes in site personnel and weather conditions. Dates of installation and removal of gravimetric briquettes at their respect field exposure sites are shown in Table 1 . Briquettes from discontinued sites ( $N J, N C$ ) were archived at ANL after weight measurements.

Quinquennial briquettes at $\mathrm{NY}$ and $\mathrm{DC}$ were exposed for a short period after the five-year exposure, to compare weight losses during that short interval with runoff measurements. These briquettes were subsequently reinstalled for additional exposure.

Table 1. Dates of gravimetric specimen installation and removal at field exposure sites.

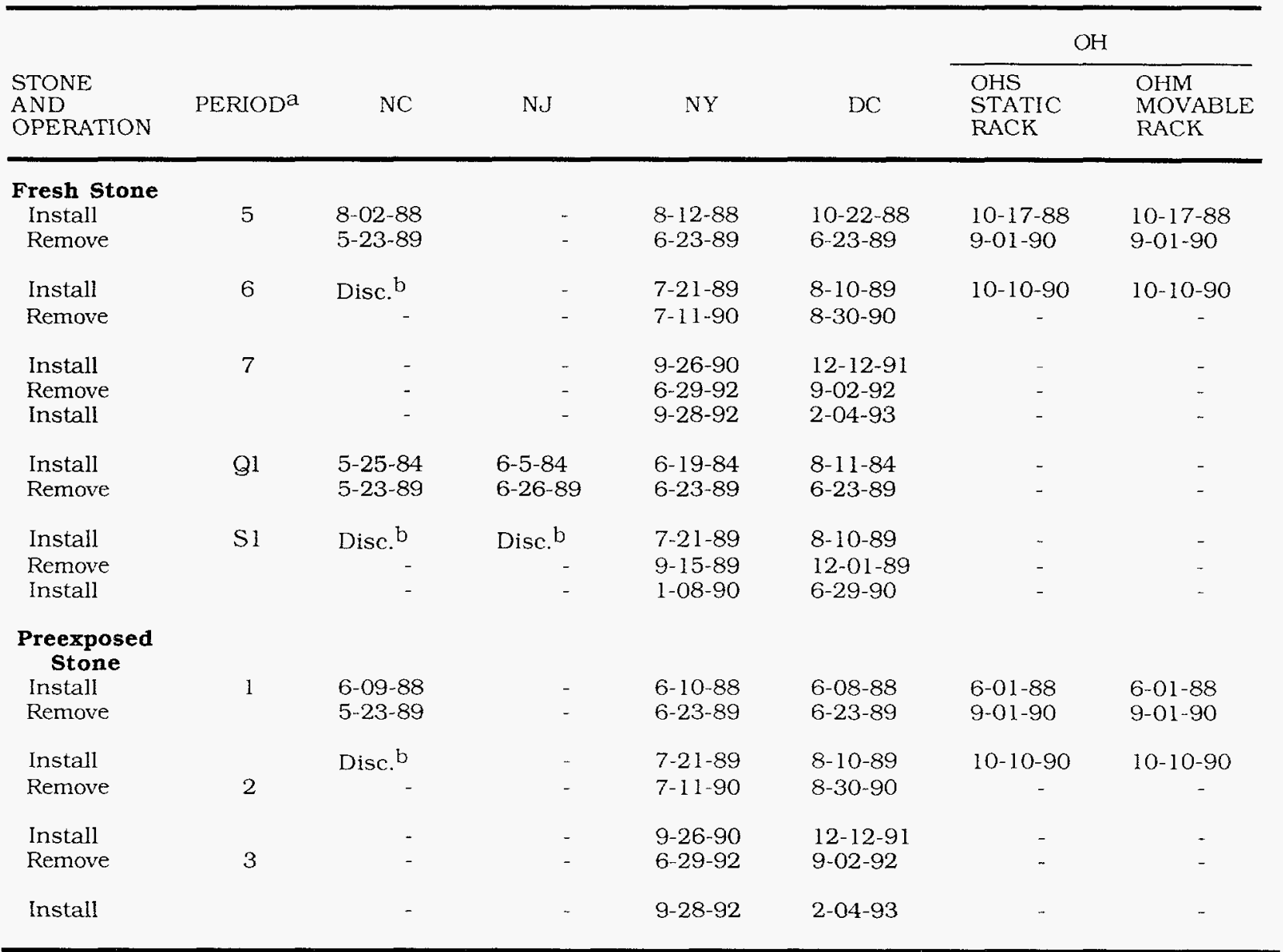

annual or multi-year exposure period designation.

${ }^{b}$ Discontinued 
Averages and standard deviation of incremental weight changes by stone type, exposure site, and exposure period are summarized in Tables 2-5. Results from the quinquennial briquettes (5 year and runoff experiment exposure) are included in these tables. Incremental weight changes in the field control and in ANL control briquettes for the same period and site are included for comparison. These control briquettes are kept indoors in sealed plastic bags, except at the DC site, where they are not kept in bags. All briquettes, including simulations and ANL controls, were dried in an oven at $51^{\circ} \mathrm{C}$ for one week prior to weighing.

Table 2. Incremental weight changes and associated recession of fresh marble briquettes for the period 1988-1992

\begin{tabular}{|c|c|c|c|c|c|}
\hline \multirow[b]{2}{*}{$\begin{array}{l}\text { PERIOD } \\
\text { AND }\end{array}$} & \multirow[b]{2}{*}{$\begin{array}{l}\text { EXPOSURE } \\
\text { TIME }\end{array}$} & \multicolumn{2}{|c|}{ EXPOSED BRIGUETTES } & \multicolumn{2}{|c|}{ AVG. LOSS (g) } \\
\hline & & $\begin{array}{l}\text { AVG. LOSS and } \\
\text { STD. DEVIATION } \\
\text { (g) }\end{array}$ & $\begin{array}{c}\text { RECESSION } \\
\text { PRORATED } \\
(\mu \mathrm{m} / \mathrm{yr})\end{array}$ & $\begin{array}{l}\text { FIELD } \\
\text { CONTROL }\end{array}$ & $\begin{array}{l}\text { LAB } \\
\text { CONTROL }\end{array}$ \\
\hline \multicolumn{6}{|c|}{$\begin{array}{l}\text { Period } 5 \\
1988-1989\end{array}$} \\
\hline $\mathrm{NC}$ & 294 & $0.2154 \pm 0.0107$ & $15.7 \pm 0.8$ & 0.0026 & 0.0026 \\
\hline NY & 315 & $0.1989 \pm 0.0030$ & $13.5 \pm 0.2$ & 0.0064 & 0.0043 \\
\hline $\mathrm{DC}$ & 244 & $0.2284 \pm 0.0030$ & $20.1 \pm 0.3$ & -0.0050 & -0.0069 \\
\hline OHSa & $449^{b}$ & $0.4383 \pm 0.0292$ & $20.9 \pm 1.4$ & 0.0000 & -0.0011 \\
\hline OHMD $^{\mathrm{a}}$ & $449^{b}$ & $0.0766 \pm$ & $3.7-$ & 0.0000 & -0.0011 \\
\hline OHMS $^{\mathrm{a}}$ & $449^{b}$ & $0.2397 \pm$ & $11.5-$ & 0.0000 & -0.0011 \\
\hline \multicolumn{6}{|c|}{$\begin{array}{l}\text { Period } 6 \\
1989-1990\end{array}$} \\
\hline NY & 355 & $0.2574 \pm 0.0011$ & $15.6 \pm 0.1$ & 0.0009 & 0.0046 \\
\hline DC & 385 & $0.2985 \pm 0.0244$ & $16.6 \pm 1.4$ & 0.0010 & 0.0031 \\
\hline \multicolumn{6}{|c|}{$\begin{array}{l}\text { Period } 7 \\
19901992\end{array}$} \\
\hline NY & 642 & $0.3644 \pm 0.0110$ & $12.2 \pm 0.4$ & -0.0016 & -0.0018 \\
\hline DC & 283 & $0.1961 \pm 0.0102$ & $14.9 \pm 0.8$ & 0.0032 & 0.0036 \\
\hline \multicolumn{6}{|c|}{$\begin{array}{l}\text { Period 91 (Guin- } \\
\text { quennia1) } \\
\text { 1984-1989 }\end{array}$} \\
\hline $\mathrm{NC}$ & 1824 & $1.2580 \pm 0.0581$ & $14.8 \pm 0.7$ & 0.0026 & 0.0026 \\
\hline NJ & 1847 & $1.9065 \pm 0.0407$ & $22.1 \pm 0.5$ & 0.0019 & 0.0041 \\
\hline NY & 1830 & $1.1743 \pm 0.0311$ & $13.8 \pm 0.4$ & 0.0064 & 0.0043 \\
\hline DC & 1777 & $1.4468 \pm 0.0216$ & $17.5 \pm 0.3$ & -0.0050 & -0.0069 \\
\hline \multicolumn{6}{|c|}{$\begin{array}{l}\text { Period Sh } 1 \text { (Quin- } \\
\text { quennial) } 1989\end{array}$} \\
\hline $\mathrm{NYC}$ & 56 & $0.0496 \pm 0.0012$ & $19.0 \pm 0.5$ & 0.0019 & -0.0041 \\
\hline $\mathrm{DC}^{\mathrm{C}}$ & 113 & $0.0956 \pm 0.0041$ & $18.2 \pm 0.8$ & 0.0042 & 0.0061 \\
\hline
\end{tabular}


Table 3. Incremental weight changes and associated recession of fresh limestone briquettes for the period 1988-1992

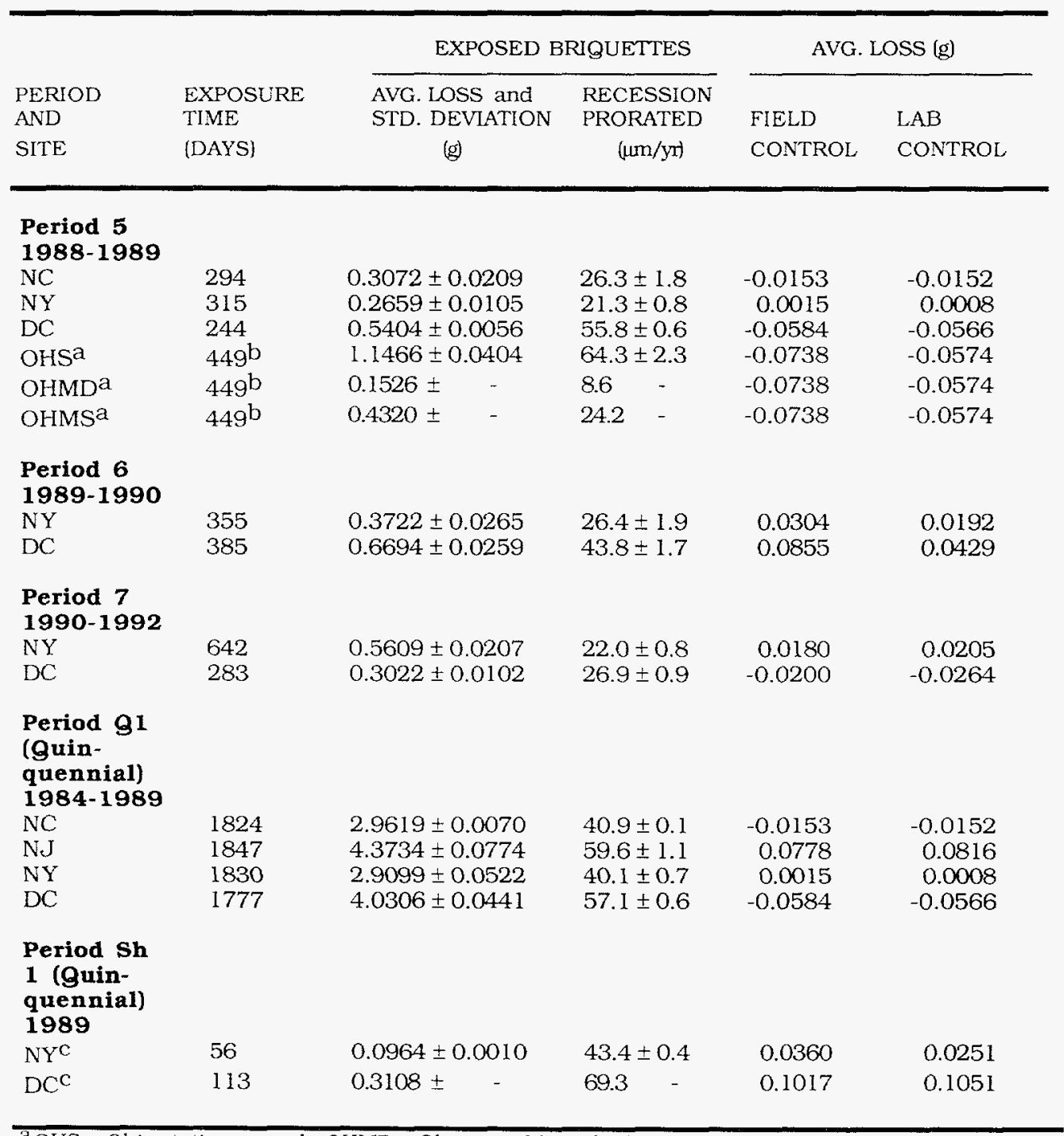

a OHS = Ohio stationary rack; OHMD = Ohio movable rack, dry regime; OHMS = OHIO movable rack. sprayed regime.

betrieved in 1990

${ }^{c}$ Quinquennial gravimetry briquettes were used for the runoff experriment. 
Table 4. Incremental weight changes and associated recession of preexposed marble briquettes for the period 1988-1992

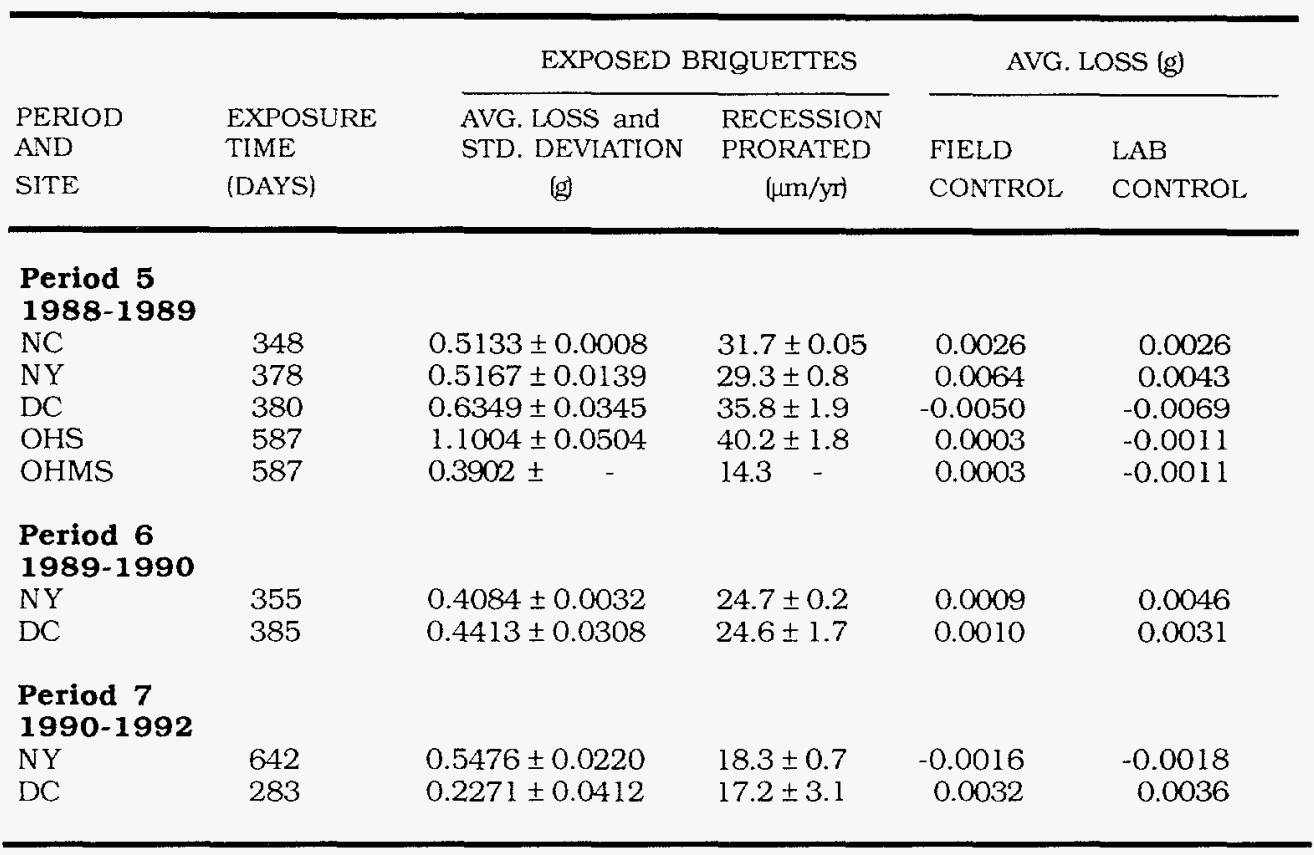

Table 5. Incremental weight changes and associated recession of preexposed limestone briquettes for the period 1988-1992

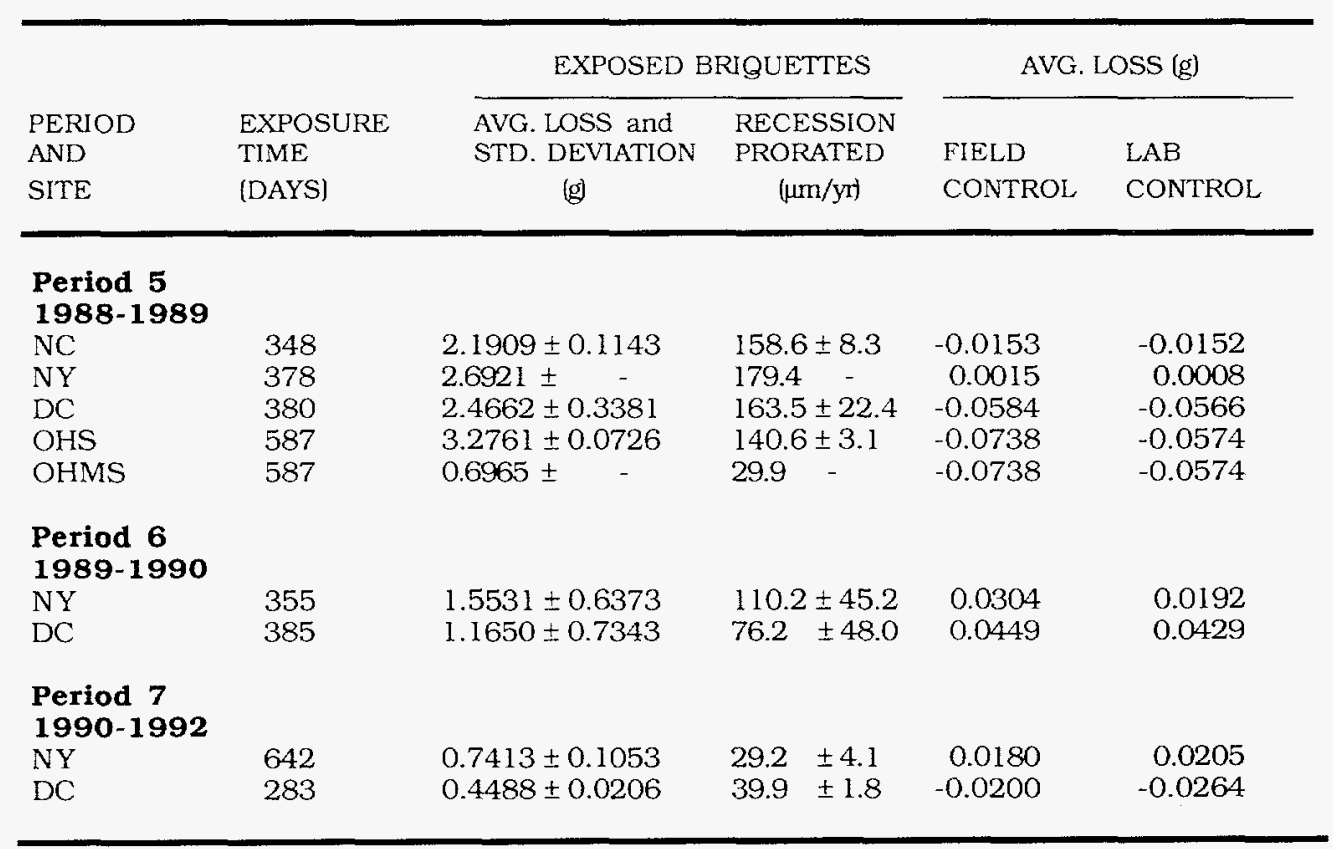


The standard deviation was calculated by

$$
\sigma=\left[\frac{\sum\left(x-\bar{x}^{2}\right)}{N}\right]^{1 / 2},
$$

where $\mathrm{x}=$ weight change of briquette,

$\bar{x}=$ average weight change,

$\mathrm{N}=$ number of briquettes (generally, $\mathrm{N}=3$ ), and

$\sigma=$ standard deviation.

$\mathrm{N}$ was chosen as the weighting factor for the standard deviation because it results in a maximum likelihood estimation that is generally used to describe populations. (N-1) is an unbiased estimator, customarily used for sampled data.

The quoted prorated recession for the exposed briquettes was calculated as follows:

Prorated recession $=\frac{\text { average gravimetric weight loss }(\mathrm{g})}{(\text { exposure area }) \times(\text { stone density })} \times \frac{365}{(\text { days of exposure })}$

The exposed area of the skyward surface of each briquette is $\approx 63 \mathrm{~cm}^{2}$, and the densities used in the calculations were $2.7 \mathrm{~g} / \mathrm{cm}^{3}$ for marble and $2.3 \mathrm{~g} / \mathrm{cm}^{3}$ for limestone.

Cumulative weight changes over the period 1988-1992 are summarized in Tables 6-10. These average changes and standard deviations were calculated by summing the changes for each briquette over the various time periods, averaging the results for each site, and calculating the standard deviation as described earlier. Weight changes of exposed briquettes are tabulated with respect to cumulative exposure time, whereas changes in field and ANL control briquettes are tabulated by cumulative elapsed time between subsequent weight measurements.

Because the weight measurements of preexposed stones were performed simultaneously with measurements on fresh stone briquettes, the same site and ANL control briquettes were used. Similarly, the same control briquettes were used for the $\mathrm{OH}$ exposure site stationary and movable racks.

Preexposed stone briquettes were reexposed at the different sites in two ways, one with the preexposed surface facing skyward (marked "up" in the Appendix), the other with the preexposed surface facing groundward (marked "down" in the Appendix). Weight changes of both exposure-type briquettes were combined to calculate the averages in Tables $4,5,8$, and 9. 
Table 6. Cumulative weight changes ( $g$ ) of fresh marble briquettes, 1988-1992

\begin{tabular}{|c|c|c|c|c|}
\hline \multirow[b]{2}{*}{ SITE } & \multicolumn{2}{|c|}{ EXPOSED BRIQUETTES } & \multicolumn{2}{|c|}{ FIELD CONTROLS } \\
\hline & $\begin{array}{l}\text { CUM. } \\
\text { EXPOSURE } \\
\text { TIME } \\
\text { (DAYS) }\end{array}$ & $\begin{array}{l}\text { AVG. LOSS } \\
\text { AND } \\
\text { STD. DEV. }\end{array}$ & $\begin{array}{l}\text { CUM. } \\
\text { ELAPSED } \\
\text { TIME } \\
\text { (DAYS) }\end{array}$ & $\begin{array}{l}\text { AVG. LOSS } \\
\text { AND } \\
\text { STD. DEV. }\end{array}$ \\
\hline $\mathrm{NC}$ & $\begin{array}{l}1407 \\
1824^{\mathrm{a}}\end{array}$ & $\begin{array}{l}1.0055 \pm .0538 \\
1.2581 \pm .0581\end{array}$ & $\begin{array}{l}1818 \\
1818\end{array}$ & $\begin{array}{l}.1172 \pm .0135 \\
.1172 \pm .0135\end{array}$ \\
\hline $\mathrm{NJ}$ & $1847^{\mathrm{a}}$ & $1.9065 \pm .0407$ & 1869 & $.0009 \pm .0007$ \\
\hline NY & $\begin{array}{l}1385 \\
1740 \\
1830^{\mathrm{a}} \\
1886^{\mathrm{b}} \\
2382\end{array}$ & $\begin{array}{r}.9708 \pm .0224 \\
1.1982 \pm .0217 \\
1.1746 \pm .0311 \\
1.2242 \pm .0302 \\
1.5625 \pm .0314\end{array}$ & $\begin{array}{l}1842 \\
2245 \\
1842 \\
1934 \\
2946\end{array}$ & $\begin{array}{l}.0068 \pm .0023 \\
.0061 \pm .0002 \\
.0068 \pm .0023 \\
.0073 \pm .0006 \\
.0035 \pm .0001\end{array}$ \\
\hline DC & $\begin{array}{l}1468 \\
1777^{a} \\
1853 \\
1890^{a} \\
2136\end{array}$ & $\begin{array}{l}1.1974 \pm .0062 \\
1.4468 \pm .0216 \\
1.4793 \pm .0146 \\
1.5424 \pm .0227 \\
1.6690 \pm .0202\end{array}$ & $\begin{array}{l}1855 \\
1855 \\
2442 \\
2007 \\
3016\end{array}$ & $\begin{array}{l}.0056 \pm .0021 \\
.0056 \pm .0021 \\
.0066 \pm .0023 \\
.0097 \pm .0023 \\
.0098 \pm .0025\end{array}$ \\
\hline $\begin{array}{l}\text { OHS } \\
\text { OHMD } \\
\text { OHMS }\end{array}$ & $\begin{array}{l}1205 \\
859 \\
859\end{array}$ & $\begin{array}{c}1.1958 \pm .0785 \\
.1921 \pm- \\
.4871 \pm \quad-\end{array}$ & $\begin{array}{l}1473 \\
1473 \\
1473\end{array}$ & $\begin{array}{l}.0138 \pm .0000 \\
.0138 \pm .0000 \\
.0138 \pm .0000\end{array}$ \\
\hline
\end{tabular}

a Quinquennial briquettes.

b OHS = Ohio stationary rack; OHMD = Ohio movable rack, dry regime; OHMS = Ohio movable rack, sprayed regime.

Table 7. Cumulative weight changes ( $g$ ) of fresh limestone briquettes, 1988-1992

\begin{tabular}{|c|c|c|c|c|}
\hline \multirow[b]{2}{*}{ SITE } & \multicolumn{2}{|c|}{ EXPOSED BRIQUETTES } & \multicolumn{2}{|c|}{ FIELD CONTROLS } \\
\hline & $\begin{array}{l}\text { CUM. } \\
\text { EXPOSURE } \\
\text { TIME } \\
\text { (DAYS) }\end{array}$ & $\begin{array}{l}\text { AVG. LOSS } \\
\text { AND } \\
\text { STD. DEV. }\end{array}$ & $\begin{array}{l}\text { CUM. } \\
\text { ELAPSED } \\
\text { TIME } \\
\text { (DAYS) }\end{array}$ & $\begin{array}{l}\text { AVG. LOSS } \\
\text { AND } \\
\text { STD. DEV. }\end{array}$ \\
\hline $\mathrm{NC}$ & $\begin{array}{l}1407 \\
1824^{a}\end{array}$ & $\begin{array}{l}2.7441 \pm .2184 \\
2.9619 \pm .0070\end{array}$ & $\begin{array}{l}1818 \\
1818\end{array}$ & $\begin{array}{l}.1172 \pm .0135 \\
.1172 \pm .0135\end{array}$ \\
\hline $\mathrm{NJ}$ & $1847^{\mathrm{a}}$ & $4.3734 \pm .0774$ & 1869 & $.1410 \pm .0073$ \\
\hline NY & $\begin{array}{l}1385 \\
1740 \\
1830^{\mathrm{a}} \\
1886^{\mathrm{b}} \\
2382\end{array}$ & $\begin{array}{l}2.5469 \pm .1315 \\
2.9191 \pm .1437 \\
2.9099 \pm .0522 \\
3.0063 \pm .0517 \\
3.4765 \pm .1965\end{array}$ & $\begin{array}{l}1842 \\
2245 \\
1842 \\
1934 \\
2946\end{array}$ & $\begin{array}{l}.1225 \pm \\
.1436 \pm \\
.1225 \pm \\
.1496 \pm \\
.1700 \pm\end{array}$ \\
\hline DC & $\begin{array}{l}1468 \\
1777^{a} \\
1853 \\
1890^{a} \\
2136\end{array}$ & $\begin{array}{l}3.4333 \pm .0771 \\
4.0306 \pm .0441 \\
4.0843 \pm .0783 \\
4.2973 \pm .0000 \\
4.3909 \pm .0827\end{array}$ & $\begin{array}{l}1855 \\
1855 \\
2442 \\
2007 \\
3016\end{array}$ & $\begin{array}{l}.1970 \pm .0124 \\
.1970 \pm .0124 \\
.2395 \pm .0138 \\
.2987 \pm .0121 \\
.2187 \pm .0139\end{array}$ \\
\hline $\begin{array}{l}\text { OHS }^{b} \\
\text { OHMD } \\
\text { OHMS }\end{array}$ & $\begin{array}{l}1205 \\
859 \\
859\end{array}$ & $\begin{array}{c}3.4061 \pm .1200 \\
.9052 \pm- \\
1.4129 \pm-\end{array}$ & $\begin{array}{l}1473 \\
1473 \\
1473\end{array}$ & $\begin{array}{l}.0138 \pm .0000 \\
.0138 \pm .0000 \\
.0138 \pm .0000\end{array}$ \\
\hline
\end{tabular}

a Buinquennial briquettes.

$\mathrm{b}_{\mathrm{OHS}}=$ Ohio stationary rack: $\mathrm{OHMD}=$ Ohio movable rack. dry regime; OHMS = Ohio movable rack, sprayed regime. 
Table 8. Cumulative weight changes (g) of preexposed marble briquettes, 1988-1992

\begin{tabular}{|c|c|c|c|c|}
\hline \multirow[b]{2}{*}{ SITE } & \multicolumn{2}{|c|}{ EXPOSED BRIQUETTES } & \multicolumn{2}{|c|}{ FIELD CONTROLS } \\
\hline & $\begin{array}{l}\text { CUM. } \\
\text { EXPOSURE } \\
\text { TIME } \\
\text { (DAYS) }\end{array}$ & $\begin{array}{l}\text { AVG. LOSS } \\
\text { AND } \\
\text { STD. DEV. }\end{array}$ & $\begin{array}{l}\text { CUM. } \\
\text { ELAPSED } \\
\text { TIME } \\
\text { (DAYS) }\end{array}$ & $\begin{array}{l}\text { AVG. LOSS } \\
\text { AND } \\
\text { STD. DEV. }\end{array}$ \\
\hline $\mathrm{NC}$ & 348 & $.5133 \pm .0008$ & 1818 & $.1172 \pm .0135$ \\
\hline NY & $\begin{array}{l}378 \\
733 \\
1375\end{array}$ & $\begin{array}{r}.5167 \pm .0139 \\
.9252 \pm .0107 \\
1.4728 \pm .0327\end{array}$ & $\begin{array}{l}1842 \\
2245 \\
2946\end{array}$ & $\begin{array}{l}.0068 \pm .0023 \\
.0061 \pm .0002 \\
.0035 \pm .0001\end{array}$ \\
\hline $\mathrm{DC}$ & $\begin{array}{l}380 \\
765 \\
1048\end{array}$ & $\begin{array}{r}.6349 \pm .0346 \\
1.0773 \pm .0640 \\
1.3044 \pm .0228\end{array}$ & $\begin{array}{l}1855 \\
2442 \\
3016\end{array}$ & $\begin{array}{l}.0056 \pm .0021 \\
.0066 \pm .0023 \\
.0098 \pm .0025\end{array}$ \\
\hline $\mathrm{OHS}^{\mathrm{a}}$ & 587 & $1.1004 \pm .0504$ & 1473 & $.0053 \pm .0008$ \\
\hline OHMS ${ }^{a}$ & 587 & $.3902 \pm$ & 1473 & $.0053 \pm .0008$ \\
\hline
\end{tabular}

Table 9. Cumulative weight changes (g) of preexposed limestone briquettes, 1988-1992

\begin{tabular}{|c|c|c|c|c|}
\hline \multirow[b]{2}{*}{ SITE } & \multicolumn{2}{|c|}{ EXPOSED BRIQUETTES } & \multicolumn{2}{|c|}{ FIELD CONTROLS } \\
\hline & $\begin{array}{l}\text { CUM. } \\
\text { EXPOSURE } \\
\text { TIME } \\
\text { (DAYS) }\end{array}$ & $\begin{array}{l}\text { AVG. LOSS } \\
\text { AND } \\
\text { STD. DEV. }\end{array}$ & $\begin{array}{l}\text { CUM. } \\
\text { ELAPSED } \\
\text { TIME } \\
\text { (DAYS) }\end{array}$ & $\begin{array}{l}\text { AVG. LOSS } \\
\text { AND } \\
\text { STD. DEV. }\end{array}$ \\
\hline $\mathrm{NC}$ & 348 & $2.1909 \pm .1143$ & 1818 & $.1172 \pm .0135$ \\
\hline NY & $\begin{array}{l}378 \\
733 \\
1375\end{array}$ & $\begin{array}{l}2.6921 \\
3.6079 \\
4.2439\end{array}$ & $\begin{array}{l}1842 \\
2245 \\
2946\end{array}$ & $\begin{array}{l}.1225- \\
.1436 \quad- \\
.1700 \quad-\end{array}$ \\
\hline $\mathrm{DC}$ & $\begin{array}{l}380 \\
765 \\
1048\end{array}$ & $\begin{array}{l}2.4662 \pm .3381 \\
3.6311 \pm .3962 \\
4.0799 \pm .4168\end{array}$ & $\begin{array}{l}1855 \\
2442 \\
3016\end{array}$ & $\begin{array}{l}.1970 \pm .0124 \\
.2395 \pm .0138 \\
.2187 \pm .0139\end{array}$ \\
\hline $\mathrm{OHS}^{\mathrm{a}}$ & 587 & $3.2761 \pm .0726$ & 1473 & $.0138 \pm .0000$ \\
\hline OHMS ${ }^{\mathrm{a}}$ & 587 & $.6965 \pm$ & 1473 & $.0138 \pm .0000$ \\
\hline
\end{tabular}


Table 10. Cumulative weight changes $(g)$ of fresh marble briquettes, 1988-1992

\begin{tabular}{|c|c|c|}
\hline \multirow{2}{*}{$\begin{array}{l}\text { CUMULATIVE } \\
\text { ELAPSED TIME } \\
\text { (DAYS) }\end{array}$} & \multicolumn{2}{|c|}{ AVG. AND STANDARD DEVIATION } \\
\hline & MARBLE & LIMESTONE \\
\hline 1818 & $.0066 \pm .0014$ & $.1409 \pm .0095$ \\
\hline 1842 & $.0113 \pm .0012$ & $.1476 \pm .0102$ \\
\hline 1855 & $.0033 \pm .0027$ & $.1854 \pm .0090$ \\
\hline 1869 & $.0072 \pm .0007$ & $.1857 \pm .0092$ \\
\hline 1934 & $.0072 \pm .0012$ & $.1727 \pm .0090$ \\
\hline 2007 & $.0094 \pm .0013$ & $.2905 \pm .0107$ \\
\hline 2226 & $.0071 \pm .0009$ & $.1474 \pm .0098$ \\
\hline 2245 & $.0064 \pm .0011$ & $.2283 \pm .0097$ \\
\hline 2442 & $.0067 \pm .0009$ & $.1668 \pm .0095$ \\
\hline 2946 & $.0049 \pm .0009$ & $.1873 \pm .0105$ \\
\hline 3016 & $.0100 \pm .0010$ & $.2019 \pm .0096$ \\
\hline
\end{tabular}

\section{DISCUSSION AND CONCLUSIONS}

The trend in weight loss discussed in Ref. 3 continued during the exposure period 1988-1992. These were (a) limestone weight losses for any given site and period were greater than marble weight losses; and (b) weight losses for both stone types were site dependent. For completeness, and to assess the effect of long-term exposure on gravimetric behavior, the results presented here incorporate data from the beginning of the exposure period (1984) until 1992. Measurements of quinquennial briquettes are included.

The average cumulative weight loss values and their variances are plotted in Figs. la and $\mathrm{b}$ for fresh marble and limestone, respectively, as functions of comulative exposure time for the various exposure sites. The shown regression lines, calculated with omission of the initial values at 0 years, can be expressed by the equations in Table 11 .

A linear relationship between weight loss and exposure time for both stone types is accentuated by the high correlation coefficients. The slope of the regression lines is a measure of the annual weight loss and/or recession at a given exposure site. These values, however, include any weight losses incurred during handling, transportation, and oven drying. Losses from handling, transportation, and oven drying can be deduced from weight changes that occurred in unexposed control briquettes from each site and in the ANL control briquettes. Results of cumulative control briquette losses are plotted in Figs. 2a and $\mathrm{b}$ for marble and limestone, respectively, as function of cumulative elapsed time between successive weighings. The weight changes of the control briquettes are very small compared to those of their exposed counterparts, and the relationship between weight changes and cumulative elapsed times is less linear, especially in marble, resulting in low correlation coefficients. It can be seen from Figs. 1a and b, however, that these changes are larger for the limestone control briquettes than for the marble ones.

Error bars are one standard deviation of the mean of three determinations (three briquettes). In some cases, briquettes were damaged and the results deleted. Preexposed (or weathered) briquettes were installed in racks at all sites, except $\mathrm{NJ}$ in 1988. Half of these weathered briquettes were reexposed with the preexposed surface facing skyward (up), the other half, with the preexposed surface facing groundward (down). 

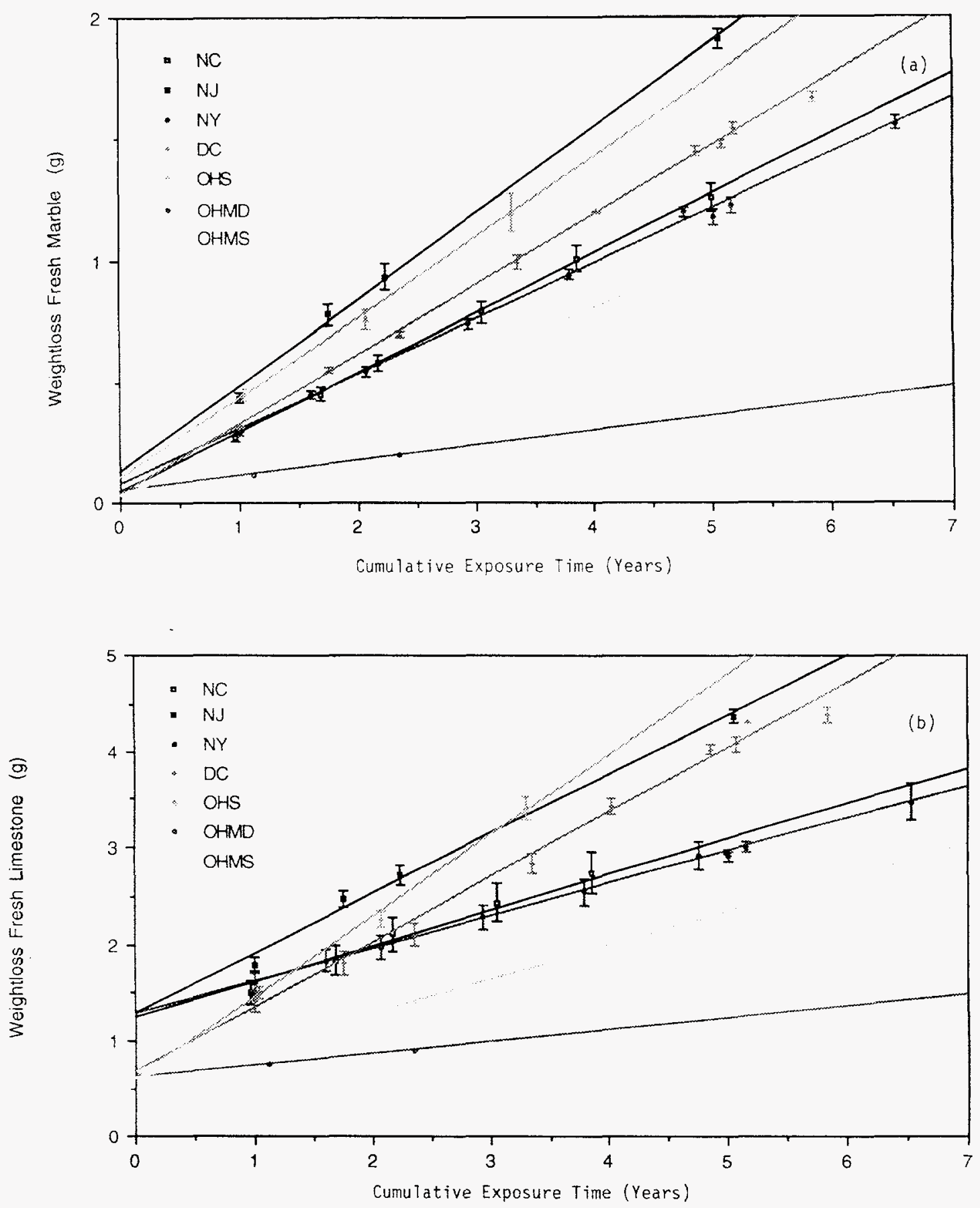

Fig. 1. Cumulative weight loss as a function of cumulative exposure time: (a) fresh marble and (b) fresh limestone. OHMD refers to the dry regime of the movable rack at Ohio; OHMS indicates the sprayed regime of the movable rack. 

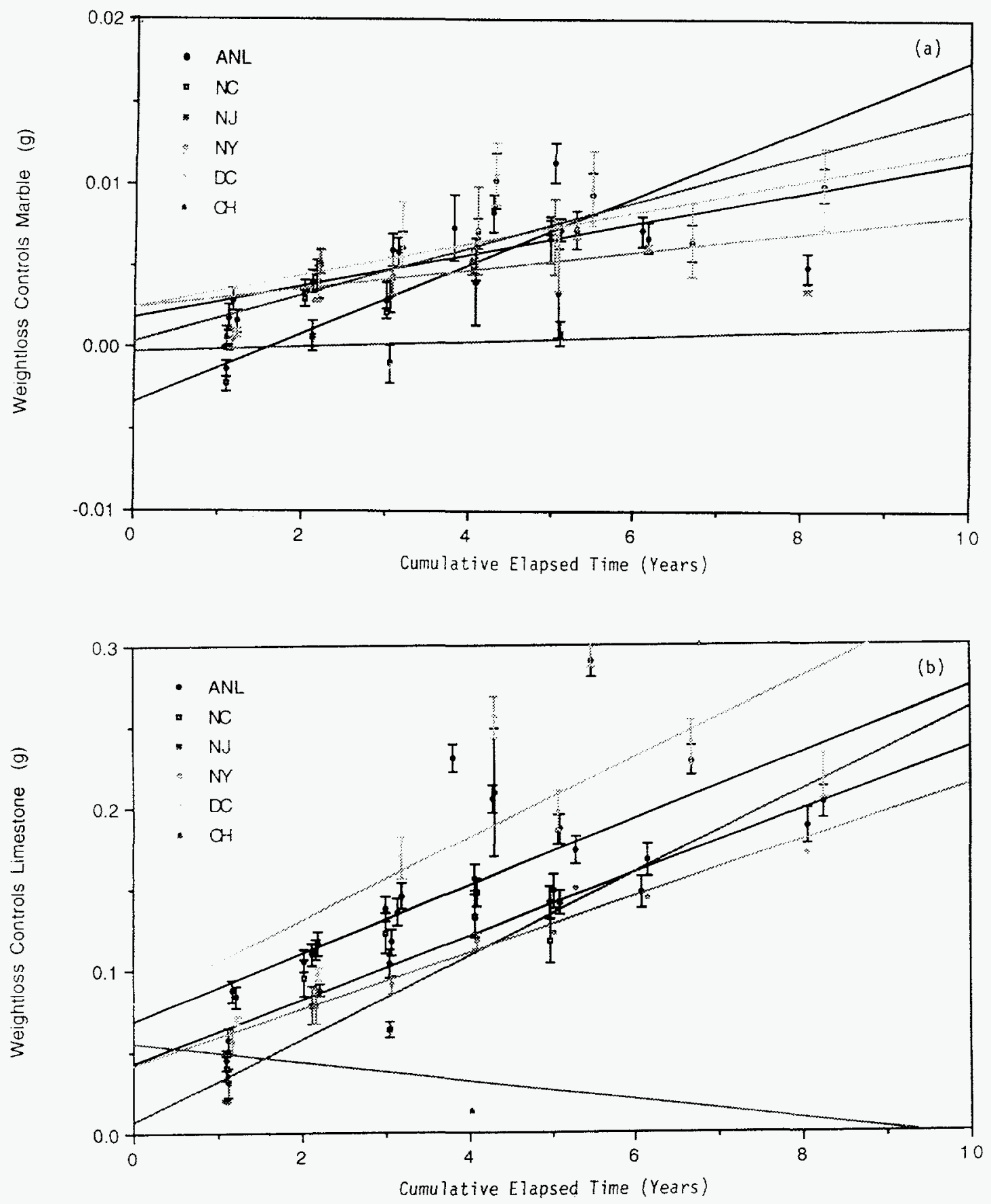

Fig. 2. Cumulative weight loss of control briquettes as a function of cumulative elapsed time for (a) marble and (b) limestone. 
For calculation of averages and standard deviations, no differentiation was made between these methods of reexposure. The results are represented graphically by regression lines in Figs. 3a and $\mathrm{b}$ for marble and limestone, respectively. The regression line equations for weight losses of preexposed briquettes are shown in Table 12.

Table 11. Equations for regression lines shown in Figures $1 a$ and $b$

\begin{tabular}{lcr}
\hline $\begin{array}{l}\text { SAMPLE } \\
\text { AND } \\
\text { SITE }\end{array}$ & EgUATIONa & $\begin{array}{c}\text { CORRELATION } \\
\text { COEFFICIENT }\end{array}$ \\
\hline & Fresh Marble & \\
NC & $y=.246 x+.040$ & .999 \\
NJ & $y=.356 x+.120$ & .997 \\
NY & $y=.227 x+.072$ & .997 \\
DC & $y=.286 x+.037$ & .998 \\
OHS & $y=.330 x+.097$ & .998 \\
OHMD & $y=.063 x+.046$ & 1.000 \\
OHMS & $y=.195 x+.028$ & 1.000 \\
& Fresh Limestone & .973 \\
NC & $y=.365 x+1.253$ & .993 \\
NJ & $y=.615 x+1.295$ & .998 \\
NY & $y=.333 x+1.291$ & .989 \\
DC & $y=.671 x+.663$ & .994 \\
OHS & $y=.835 x+.612$ & 1.000 \\
OHMD & $y=.124 x+.613$ & 1.000 \\
OHMS & $y=.352 x+.586$ & \\
\hline ay = cumulative weight loss in grams: $\mathrm{x}=$ cumulative exposure period in years
\end{tabular}

Table 12. Equations for regression lines shown in Figures $3 a$ and $b$

\begin{tabular}{lcc}
\hline $\begin{array}{l}\text { SAMPLE } \\
\text { AND } \\
\text { SITE }\end{array}$ & EgUATIONa & $\begin{array}{c}\text { CORRELATION } \\
\text { COEFFICIENT }\end{array}$ \\
\hline & Fresh Marble & - \\
NC & single point & .994 \\
NY & $y=.3465 x+.1861$ & .991 \\
DC & $y=.3690 x+.2670$ & - \\
OHS & single point & - \\
OHMS & single point & - \\
& Fresh Limestone & .930 \\
NC & single point & .974 \\
NY & $y=.5452 x+2.2788$ & - \\
DC & $y=.8948 x+1.6014$ & - \\
OHS & single point & - \\
OHMS & single point & \\
\hline
\end{tabular}

$\mathrm{a}_{\mathrm{y}}=$ cumulative weight loss in grams: $\mathrm{x}=$ cumulative exposure time in years 

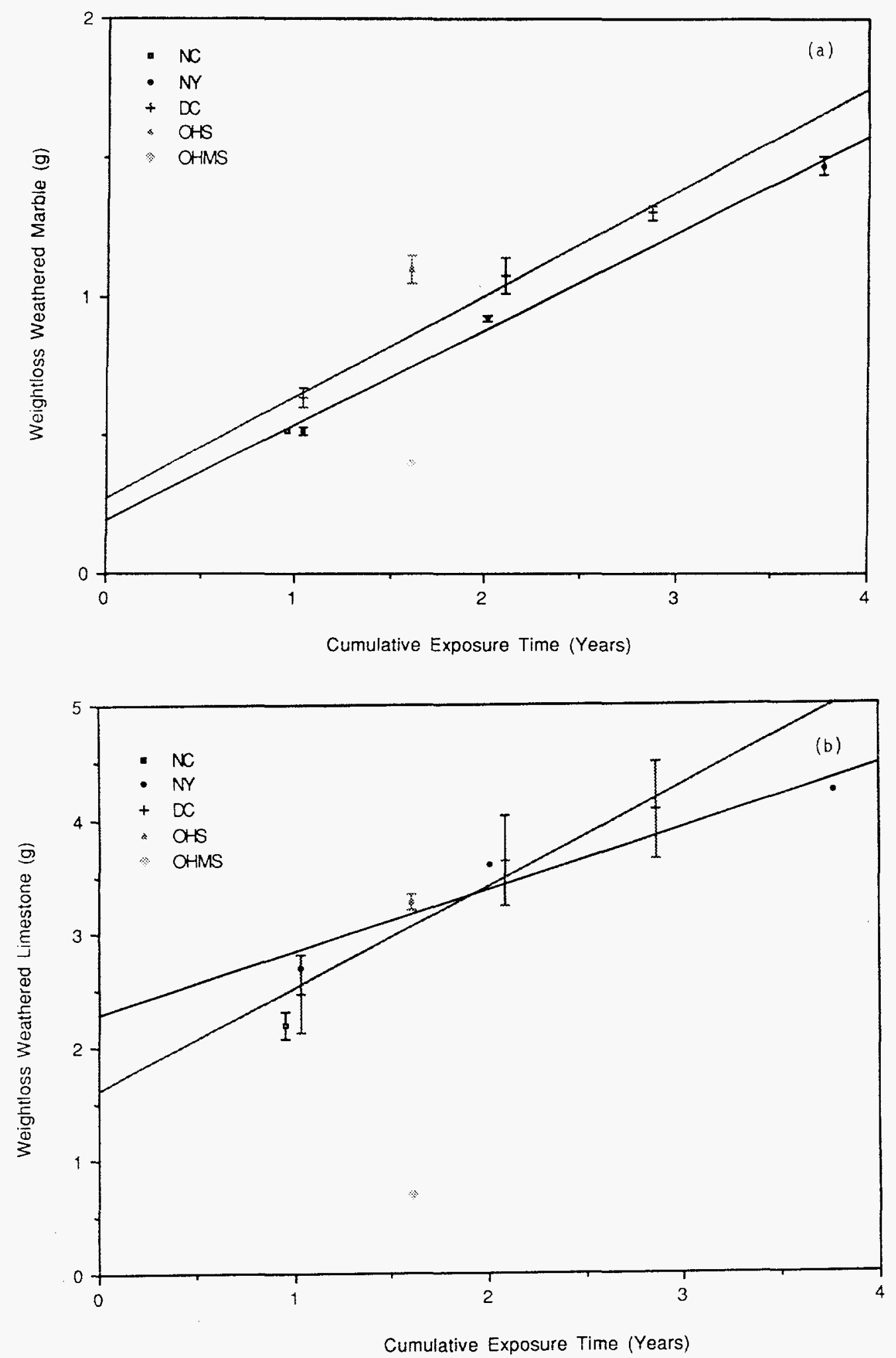

Fig. 3. Cumulative weight loss of preexposed briquettes as a function of cumulative exposure time for (a) marble and (b) limestone. 
At the two sites where more than one data point was obtained for preexposed briquettes, a linear relationship between weight loss as function of exposure time is evident from the high correlation coefficient. Determination of any trend in weight loss at the sites where only one measurement was available awaits additional data.

From the slopes of the regression lines, a prorated annual weight loss and/or recession can be deduced. If the prorated annual recession of control briquettes is subtracted from that of exposed briquettes, we obtain the actual recession due to exposure only; see Table 13. A comparison of results shown in Table 11 with those shown in Table 7 of Ref. 3 indicates, in most cases, a slight reduction of recession rate with prolonged exposure. Poor correlation in the weight changes of the simulation and control briquettes will significantly affect the results. The prorated recession rate of briquettes from preexposed materials is greater than that of briquettes from fresh materials. A reason for this finding could be the difference in the origin of the materials and a shorter current exposure time. A problem encountered with the gravimetry samples was chipping of the briquettes, especially the limestone briquettes, during retrieval or transport, thus restricting cumulative weight loss calculations to fewer briquettes.

Table 13. Average recession rates $(\mu \mathrm{m} / \mathrm{yr})$ of exposed briquettes, by exposure site

\begin{tabular}{lccc}
\hline $\begin{array}{l}\text { SAMPLE } \\
\text { AND }\end{array}$ & $\begin{array}{c}\text { EXPOSED } \\
\text { SITE }\end{array}$ & $\begin{array}{c}\text { CONTROL } \\
\text { BRIQUETTES }\end{array}$ & $\begin{array}{c}\text { EXPOSURE } \\
\text { ALONE }\end{array}$ \\
\hline Fresh Marble & & & \\
NC & 14.5 & .1 & 14.4 \\
NJ & 20.9 & .0 & 20.9 \\
NY & 13.4 & .0 & 13.4 \\
DC & 16.8 & .1 & 16.7 \\
OHS & 19.4 & .1 & 19.3 \\
OHMD & 3.7 & .1 & 3.6 \\
OHMS & 11.5 & .1 & 11.4 \\
Weathered Marble & & & - \\
NC & Single point &. & 20.4 \\
NY & 20.4 & .1 & 21.6 \\
DC & 21.7 & - & - \\
OHS & Single point & - & - \\
OHMS & Single point & & \\
Fresh Limestone & & 1.3 & 23.9 \\
NC & 25.2 & 1.7 & 40.7 \\
NJ & 42.4 & 1.2 & 21.8 \\
NY & 23.0 & 1.7 & 44.6 \\
DC & 46.3 & .6 & 57.0 \\
OHS & 57.6 & .6 & 8.0 \\
OHMD & 8.6 & .6 & 23.7 \\
OHMS & 24.3 & - & - \\
Weathered Limestone & & 1.2 & -1 \\
NC & Single point & 1.7 & - \\
NY & 37.6 & - & -1 \\
DC & 61.8 & & \\
OHS & Single point & & \\
OHMS & Single point & & \\
\hline & & & \\
\hline
\end{tabular}


Incomplete data, the result of instrument failure 4,5 made it necessary to abandon efforts to correlate weight losses with amounts of precipitation during the exposure periods. The same is true for other atmospheric data, such as $\mathrm{SO}_{2}$ and $\mathrm{H}^{+}$concentrations. We anticipate that all of the data will be available after the 10-year exposure period.

Holographic recession and roughness measurements were postponed until the end of the 10-year exposure period because of budgetary restrictions. A comparison of the two recession measurement methods will also be postponed until then.

The results obtained by gravimetry can be summarized as follows:

1. The linear trend of weight loss or recession as a function of exposure time continued over the period 1984-1992, with a high correlation coefficient.

2. Prorated recession for marble, ranging from 11 to $21 \mu \mathrm{m} /$ year, is half the value for limestone, which ranged from 21 to $45 \mu \mathrm{m} /$ year, and is dependent on exposure site.

3. Weight changes in simulation and control briquettes are very small and show poor correlation, indicating effects of drying and ambient measurement conditions.

4. The smallest weight losses/recession occurred at $\mathrm{OH}$ in the movable rack, dry regime, indicating a strong influence of the amount of rain.

5. A statistical evaluation of rain effect could not be performed, because site data were incomplete.

6. Weight losses of quinquennial briquettes correspond well with the cumulative losses of annual briquettes.

Forthcoming gravimetry results will allow assessment of recession over even longer cumulative exposure times and comparison of the results with those from laser interferometry measurements.

\section{ACKNOWLEDGMENTS}

It is a pleasure to acknowledge the valuable assistance and cooperation of many people in this investigation. In particular, the author thanks Susan I. Sherwood of the NPS Project Office for her encouragement, support, and advice; and field site operators Curtis Moore (NC), Paul Fiechler (NJ), Ray Masters (NY), NPS personnel (DC), and Dan Zorbini (OH) for their assistance in briquette installation, exchange, and removal. 


\section{REFERENCES}

1. "Acid Rain Site Management Plan for Dimension Stone," Vol. 2, National Park Service and Argonne National Laboratory, Dec. 1988.

2. "Weight Losses of Marble and Limestone Briquettes Exposed to Outdoor Environments in the Eastern United States," C. A. Youngdahl, Argonne National Laboratory Report ANL-87-56 (1987).

3. "Weight Losses of Marble and Limestone Briquettes Exposed to Outdoor Environments in the Eastern United States," Results of Exposure 1984-1988, K. J. Reimann, Argonne National Laboratory Report ANL-90/24 (1990).

4. S. D. Cramer, private communication, U.S. Department of the Interior, Bureau of Mines, Albany, OR (1993).

5. D. A. Dolske, Illinois State Water Survey, Atmospheric Sciences Division, Champaign, IL (1995). 
Appendix:

Weight Losses from Individual Briquettes

(1988-1992) 
Table A.1. Weight changes $(g)$ in exposed and control briquettes: fresh stone, annuals, 1988-1989

\begin{tabular}{|c|c|c|c|c|c|c|c|c|}
\hline \multirow{2}{*}{$\begin{array}{l}\text { SAMPLE } \\
\text { AND } \\
\text { SITE }\end{array}$} & \multirow{2}{*}{$\begin{array}{l}\text { EXPOS. } \\
\text { TIME, } \\
\text { DAYS }\end{array}$} & \multirow[b]{2}{*}{ SLOT } & \multicolumn{2}{|c|}{ EXPOSED BRIQUETTES } & \multicolumn{2}{|c|}{ FIELD CONTROLS } & \multicolumn{2}{|c|}{ LAB CONTROLS } \\
\hline & & & $\begin{array}{c}\text { SAMPLE } \\
\text { NO. }\end{array}$ & $\begin{array}{l}\text { WEIGHT } \\
\text { CHANGE }\end{array}$ & $\begin{array}{c}\text { SAMPLE } \\
\text { NO. }\end{array}$ & $\begin{array}{l}\text { WEIGHT } \\
\text { CHANGE }\end{array}$ & $\begin{array}{c}\text { SAMPLE } \\
\text { NO. }\end{array}$ & $\begin{array}{l}\text { WEIGHT } \\
\text { CHANGE }\end{array}$ \\
\hline \multicolumn{9}{|l|}{ Marble: } \\
\hline $\mathrm{NC}$ & 294 & $\begin{array}{l}263 \\
207 \\
265\end{array}$ & $\begin{array}{l}\text { H14-17 } \\
\text { G36-19 } \\
\text { G26-02 }\end{array}$ & $\begin{array}{l}0.2280 \\
0.2019 \\
0.2163\end{array}$ & $\begin{array}{l}\text { G36-05 } \\
\text { H36-21 } \\
\text { I14-01 }\end{array}$ & $\begin{array}{l}0.0023 \\
0.0026 \\
0.0030\end{array}$ & $\begin{array}{l}\mathrm{H} 14-18 \\
\text { G36-23 } \\
\text { G26-10 }\end{array}$ & $\begin{array}{l}0.0044 \\
0.0018 \\
0.0017\end{array}$ \\
\hline NY & 315 & $\begin{array}{l}263 \\
207 \\
265\end{array}$ & $\begin{array}{l}\text { H14-15 } \\
\text { G36-17 } \\
\text { G26-22 }\end{array}$ & $\begin{array}{l}0.2028 \\
0.1954 \\
0.1984\end{array}$ & $\begin{array}{l}\text { I1 4-03 } \\
\text { K36-20 } \\
\text { G36-07 }\end{array}$ & $\begin{array}{r}0.0047 \\
-0.0053 \\
0.0198\end{array}$ & $\begin{array}{l}\text { H14-18 } \\
\text { G36-23 } \\
\text { G26-10 }\end{array}$ & $\begin{array}{l}0.0039 \\
0.0046 \\
0.0045\end{array}$ \\
\hline $\mathrm{DC}$ & 244 & $\begin{array}{l}263 \\
207 \\
265\end{array}$ & $\begin{array}{l}\text { H1 1 -10 } \\
\text { G36-22 } \\
\text { G26-11 }\end{array}$ & $\begin{array}{l}0.8559^{a} \\
0.2254 \\
0.2313\end{array}$ & $\begin{array}{l}\text { H36-22 } \\
\text { K36-22 } \\
\text { G36-08 }\end{array}$ & $\begin{array}{l}-0.0049 \\
-0.0049 \\
-0.0053\end{array}$ & $\begin{array}{l}\text { H14-18 } \\
\text { G36-23 } \\
\text { G26-10 }\end{array}$ & $\begin{array}{l}-0.0042 \\
-0.0064 \\
-0.0101\end{array}$ \\
\hline $\mathrm{OH}^{\mathrm{a}}$ & 449 & $\begin{array}{l}263 \\
207 \\
265\end{array}$ & $\begin{array}{l}\text { G34-21 } \\
\text { K13-08 } \\
\text { G22-17 }\end{array}$ & $\begin{array}{l}0.4091 \\
0.4675 \\
\text { missing }\end{array}$ & $\begin{array}{l}\text { K15-13 } \\
\text { G22-03 } \\
\text { G34-12 }\end{array}$ & $\begin{array}{r}0.0003 \\
-0.0009 \\
0.0007\end{array}$ & $\begin{array}{l}\text { H14-18 } \\
\text { G36-23 } \\
\text { G26-10 }\end{array}$ & $\begin{array}{l}-0.0007 \\
-0.0015 \\
-0.0011\end{array}$ \\
\hline $\begin{array}{l}\text { OHMD }^{\mathrm{b}, \mathrm{c}} \\
\text { OHMS }^{\mathrm{c}, \mathrm{c}}\end{array}$ & $\begin{array}{ll}\text { c } & 449 \\
\text { d } & 449\end{array}$ & $\begin{array}{l}353 \\
335\end{array}$ & $\begin{array}{l}\text { G24-19 } \\
\text { K14-14 }\end{array}$ & $\begin{array}{l}0.0766 \\
0.2397\end{array}$ & - & - & - & - \\
\hline Limestor & ne: & & & & & & & \\
\hline $\mathrm{NC}$ & 294 & $\begin{array}{l}163 \\
107 \\
165\end{array}$ & $\begin{array}{l}\text { HU5-05 } \\
\text { IL4-22 } \\
\text { GL7-09 }\end{array}$ & $\begin{array}{l}0.3191 \\
0.2778 \\
0.3247\end{array}$ & $\begin{array}{l}\text { HU6-01 } \\
\text { GU1-06 } \\
\text { HU4-24 }\end{array}$ & $\begin{array}{l}-0.0165 \\
-0.0147 \\
-0.0146\end{array}$ & $\begin{array}{l}\text { HU1-15 } \\
\text { HU1-20 } \\
\text { GL7-03 }\end{array}$ & $\begin{array}{l}-0.0148 \\
-0.0178 \\
-0.0129\end{array}$ \\
\hline NY & 315 & $\begin{array}{l}163 \\
107 \\
165\end{array}$ & $\begin{array}{l}\text { HU5-22 } \\
\text { ILA-03 } \\
\text { GL7-18 }\end{array}$ & $\begin{array}{l}0.2715 \\
0.2511 \\
0.2750\end{array}$ & $\begin{array}{l}\text { GU1-12 } \\
\text { HU6-24 } \\
\text { HU5-18 }\end{array}$ & $\begin{array}{l}0.0015 \\
0.2005^{\mathrm{a}} \\
0.2845^{\mathrm{a}}\end{array}$ & $\begin{array}{l}\mathrm{HU} 1-15 \\
\mathrm{HU} 1-20 \\
\mathrm{GL} 7-03\end{array}$ & $\begin{array}{r}0.0007 \\
-0.0020 \\
0.0036\end{array}$ \\
\hline $\mathrm{DC}$ & 244 & $\begin{array}{l}163 \\
107 \\
165\end{array}$ & $\begin{array}{l}\text { HU5-10 } \\
\text { IL4-19 } \\
\text { GL7-15 }\end{array}$ & $\begin{array}{l}0.5348 \\
2.1678^{a} \\
0.5459\end{array}$ & $\begin{array}{l}\text { GL7-04 } \\
\text { GL7-11 } \\
\text { IU4-15 }\end{array}$ & $\begin{array}{l}-0.0602 \\
-0.0575 \\
-0.0575\end{array}$ & $\begin{array}{l}\text { HU1-15 } \\
\text { HU 1-20 } \\
\text { GL7-03 }\end{array}$ & $\begin{array}{l}-0.0587 \\
-0.0573 \\
-0.0537\end{array}$ \\
\hline $\mathrm{OH}^{\mathrm{a}}$ & 449 & $\begin{array}{l}163 \\
107 \\
165\end{array}$ & $\begin{array}{l}\text { IL8-22 } \\
\text { HL2-12 } \\
\text { GL6-15 }\end{array}$ & $\begin{array}{l}1.0897 \\
1.1701 \\
1.1799\end{array}$ & $\begin{array}{l}\text { HL2-05 } \\
\text { IL8-02 } \\
\text { GL6-09 }\end{array}$ & $\begin{array}{l}-0.0764 \\
-0.0686 \\
-0.0765\end{array}$ & $\begin{array}{l}\text { HU1-15 } \\
\text { HU1-20 } \\
\text { GL7-03 }\end{array}$ & $\begin{array}{l}-0.0585 \\
-0.0598 \\
-0.0540\end{array}$ \\
\hline $\begin{array}{l}\text { OHMD }^{\mathrm{b}, c} \\
\text { OHMS }^{\mathrm{C}, \mathrm{d}}\end{array}$ & $\begin{array}{ll}\text { c } & 449 \\
\text { d } & 449\end{array}$ & $\begin{array}{l}338 \\
320\end{array}$ & $\begin{array}{l}\text { IL8-06 } \\
\text { HL2- } 19\end{array}$ & $\begin{array}{l}0.1526 \\
0.4320\end{array}$ & - & - & - & - \\
\hline
\end{tabular}

achipped stone.

bOHMD - Ohio site movable rack - dry regime.

retrieved in 1990.

dOHMS - Ohio site movable rack - sprayed regime. 
Table A.2. Weight changes (g) in exposed and control briquettes: fresh stone, annuals, 1989-1990 and 1990-1992

\begin{tabular}{|c|c|c|c|c|c|c|c|c|}
\hline \multirow{2}{*}{$\begin{array}{l}\text { SAMPLE } \\
\text { PERIOD. } \\
\text { SITE }\end{array}$} & \multirow{2}{*}{$\begin{array}{l}\text { EXPOS. } \\
\text { TIME. } \\
\text { DAYS }\end{array}$} & \multirow[b]{2}{*}{ SLOT } & \multicolumn{2}{|c|}{ EXPOSED BRIQUETTES } & \multicolumn{2}{|c|}{ FIELD CONTROLS } & \multicolumn{2}{|c|}{ LAB CONTROLS } \\
\hline & & & $\begin{array}{c}\text { SAMPLE } \\
\text { NO. }\end{array}$ & $\begin{array}{l}\text { WEIGHT } \\
\text { CHANGE }\end{array}$ & $\begin{array}{c}\text { SAMPLE } \\
\text { NO. }\end{array}$ & $\begin{array}{l}\text { WEIGHT } \\
\text { CHANGE }\end{array}$ & $\begin{array}{c}\text { SAMPLE } \\
\text { NO. }\end{array}$ & $\begin{array}{l}\text { WEIGHT } \\
\text { CHANGE }\end{array}$ \\
\hline Marble: & Period & $1989-$ & & & & & & \\
\hline NY & 355 & $\begin{array}{l}263 \\
207 \\
265\end{array}$ & $\begin{array}{l}\text { H14-15 } \\
\text { G36-17 } \\
\text { G26-22 }\end{array}$ & $\begin{array}{l}0.2559 \\
0.2585 \\
0.2578\end{array}$ & $\begin{array}{l}\text { I14-03 } \\
\text { K36-20 } \\
\text { G36-07 }\end{array}$ & $\begin{array}{r}-0.0032 \\
0.0018 \\
0.0041\end{array}$ & $\begin{array}{l}\text { H14-18 } \\
\text { G36-23 } \\
\text { G26-10 }\end{array}$ & $\begin{array}{l}-0.0042 \\
-0.0050 \\
-0.0047\end{array}$ \\
\hline DC & 385 & $\begin{array}{l}263 \\
207 \\
265\end{array}$ & $\begin{array}{l}\text { H 14-10 } \\
\text { G36-22 } \\
\text { G26-11 }\end{array}$ & $\begin{array}{l}0.3316 \\
0.2735 \\
0.2903\end{array}$ & $\begin{array}{l}\text { H36-22 } \\
\text { K36-22 } \\
\text { G36-08 }\end{array}$ & $\begin{array}{l}0.0008 \\
0.0021 \\
0.0002\end{array}$ & $\begin{array}{l}\text { H14-18 } \\
\text { G36-23 } \\
\text { G26-10 }\end{array}$ & $\begin{array}{l}0.0009 \\
0.0017 \\
0.0067\end{array}$ \\
\hline
\end{tabular}

Limestone: Period 1989 - 1990

$\begin{array}{lllllllll}\text { NY } & 355 & 163 & \text { HU5-22 } & 0.4035 & \text { GU1-12 } & 0.0211 & \text { HU1-15 } & 0.0209 \\ & & 107 & \text { IL4-03 } & 0.3397 & \text { HU6-24 } & 0.0345 & \text { HU1-20 } & 0.0203 \\ & & 165 & \text { GL7-18 } & 0.3724 & \text { HU5-18 } & 0.0357 & \text { GL7-03 } & 0.0163 \\ \text { DC } & & & & & & & & \\ & 385 & 163 & \text { HU5-10 } & 0.6498 & \text { GL7-04 } & 0.1667^{\mathrm{a}} & \text { HU1-15 } & 0.0456 \\ & & 107 & \text { IL4-19 } & 0.7060 & \text { GL7-11 } & 0.0441 & \text { HU1-20 } & 0.0429 \\ & & 165 & \text { GL7-15 } & 0.6523 & \text { IU4-15 } & 0.0457 & \text { GL7-03 } & 0.0403\end{array}$

Marble: Period $1990-1992$

$\begin{array}{lllllllll}\text { NY } & 642 & 263 & \text { H14-15 } & 0.3770 & \text { I14-03 } & -0.0025 & \text { H14-18 } & -0.0025 \\ & & 207 & \text { G36-17 } & 0.3501 & \text { K36-20 } & -0.0028 & \text { G36-23 } & -0.0011 \\ & & 265 & \text { G26-22 } & 0.3660 & \text { G36-07 } & 0.0006 & \text { G26-10 } & -0.0018 \\ \text { DC } & & & & & & & & \\ & 283 & 263 & \text { H14-10 } & 0.2090 & \text { H36-22 } & 0.0042 & \text { H14-18 } & 0.0038 \\ & & 207 & \text { G36-22 } & 0.1841 & \text { K36-22 } & 0.0013 & \text { G36-23 } & 0.0036 \\ & & 265 & \text { G26-11 } & 0.1953 & \text { G36-08 } & 0.0041 & \text { G26-10 } & 0.0034\end{array}$

Limestone: Period $1990-1992$

\begin{tabular}{|c|c|c|c|c|c|c|c|c|}
\hline$N Y$ & 642 & $\begin{array}{l}163 \\
107 \\
165\end{array}$ & $\begin{array}{l}\text { HU5-22 } \\
\text { ILA-O3 } \\
\text { GL7-18 }\end{array}$ & $\begin{array}{l}0.8371^{\mathrm{a}} \\
0.5402 \\
0.5815\end{array}$ & $\begin{array}{l}\text { GU1-12 } \\
\text { HU6-24 } \\
\text { HU5-18 }\end{array}$ & $\begin{array}{r}0.0264 \\
-0.0017 \\
0.0293\end{array}$ & $\begin{array}{l}\text { HU } 1-15 \\
\text { HU } 1-20 \\
\text { GL7-O3 }\end{array}$ & $\begin{array}{l}0.0228 \\
0.0195 \\
0.0193\end{array}$ \\
\hline$D C$ & 283 & $\begin{array}{l}163 \\
107 \\
165\end{array}$ & $\begin{array}{l}\text { HU5-10 } \\
\text { IL4-19 } \\
\text { GL7-15 }\end{array}$ & $\begin{array}{l}0.3022 \\
0.2880 \\
0.3110\end{array}$ & $\begin{array}{l}\text { GL7-04 } \\
\text { GL7-11 } \\
\text { IU4-15 }\end{array}$ & $\begin{array}{l}-0.0184 \\
-0.0207 \\
-0.0209\end{array}$ & $\begin{array}{l}\text { HUl-15 } \\
\text { HU 1-20 } \\
\text { GL7-03 }\end{array}$ & $\begin{array}{l}0.0279 \\
0.0270 \\
0.0243\end{array}$ \\
\hline
\end{tabular}

aChipped stone. 
Table A.3. Weight changes (g) in exposed and control briquettes: fresh stone, quinquennials, 1984-1989

\begin{tabular}{|c|c|c|c|c|c|c|c|c|}
\hline \multirow{3}{*}{$\begin{array}{l}\text { SAMPLE } \\
\text { AND } \\
\text { SITE }\end{array}$} & \multirow{3}{*}{$\begin{array}{l}\text { EXPOS. } \\
\text { TIME, } \\
\text { DAYS }\end{array}$} & \multirow[b]{3}{*}{ SLOT } & \multicolumn{2}{|c|}{ EXPOSED BRIQUETTES } & \multicolumn{2}{|c|}{ FIELD CONTROLS } & \multicolumn{2}{|c|}{ LAB CONTROLS } \\
\hline & & & SAMPLE & WEIGHT & SAMPLE & WEIGHT & SAMPLE & WEIGHT \\
\hline & & & No. & CHANGE & No. & CHANGE & NO. & CHANGE \\
\hline
\end{tabular}

Marble: Period $1984-1989$

\begin{tabular}{llllllllr} 
NC & 1824 & 219 & E26-13 & $37.8916 \mathrm{a}$ & G36-05 & 0.0078 & H14-18 & 0.0047 \\
& & 272 & A33-08 & 1.1999 & H36-21 & 0.0071 & G36-23 & 0.0079 \\
& & 245 & I36-21 & 1.3161 & $114-01$ & 0.0070 & G26-10 & 0.0082 \\
NJ & 1847 & 219 & A33-14 & 1.8518 & I14-02 & 0.0000 & H14-18 & 0.0064 \\
& & 272 & A33-22 & 1.9182 & K36-18 & 0.0017 & G36-23 & 0.0081 \\
& & 245 & I36-01 & 1.9494 & G36-06 & 0.0011 & G26-10 & 0.0070 \\
NY & \multirow{2}{*}{1830} & 219 & A33-15 & 1.1844 & I14-03 & 0.0091 & H14-18 & 0.0098 \\
& & 272 & A33-06 & 1.2069 & K36-20 & 0.0045 & G36-23 & 0.0127 \\
& & 245 & I36-06 & 1.1326 & G36-07 & $0.7865^{\mathrm{a}}$ & G26-10 & 0.0114 \\
& & & & & & & & \\
DC & 1777 & 219 & A33-19 & 1.4587 & H36-22 & 0.0083 & H14-18 & 0.0042 \\
& & 272 & A33-03 & 1.4652 & K36-22 & 0.0051 & G36-23 & 0.0061 \\
& & 245 & I36-10 & 1.4164 & G36-08 & 0.0033 & G26-10 & -0.0003
\end{tabular}

Limestone: Period $1984-1989$

\begin{tabular}{|c|c|c|c|c|c|c|c|c|}
\hline $\mathrm{NC}$ & 1824 & $\begin{array}{l}119 \\
172 \\
145\end{array}$ & $\begin{array}{l}\text { HU5-14 } \\
\text { IL4-06 } \\
\text { GL7-22 }\end{array}$ & $\begin{array}{l}2.9589 \\
2.9716 \\
2.9552\end{array}$ & $\begin{array}{l}\text { HU6-01 } \\
\text { GU 1-06 } \\
\text { HU4-24 }\end{array}$ & $\begin{array}{l}0.1043 \\
0.1359 \\
0.1114\end{array}$ & $\begin{array}{l}\text { HU 1-15 } \\
\text { HU 1-20 } \\
\text { GL7-03 }\end{array}$ & $\begin{array}{l}0.1474 \\
0.1274 \\
0.1478\end{array}$ \\
\hline $\mathrm{NJ}$ & 1847 & $\begin{array}{l}119 \\
172 \\
145\end{array}$ & $\begin{array}{l}\text { HU5-23 } \\
\text { ILA-18 } \\
\text { GL7-06 }\end{array}$ & $\begin{array}{l}4.4736 \\
4.2852 \\
4.3614\end{array}$ & $\begin{array}{l}\text { GU1-07 } \\
\text { HU6-04 } \\
\text { HU5-04 }\end{array}$ & $\begin{array}{l}1.4230^{\mathrm{a}} \\
0.1483 \\
0.1337\end{array}$ & $\begin{array}{l}\text { HU 1-15 } \\
\text { HU1-20 } \\
\text { GL7-03 }\end{array}$ & $\begin{array}{l}0.1941 \\
0.1731 \\
0.1890\end{array}$ \\
\hline $\mathrm{NY}$ & 1830 & $\begin{array}{l}119 \\
172 \\
145\end{array}$ & $\begin{array}{l}\text { HU5-09 } \\
\text { IL4-11 } \\
\text { GL7-19 }\end{array}$ & $\begin{array}{l}2.8590 \\
2.8891 \\
2.9817\end{array}$ & $\begin{array}{l}\text { GU } 1-12 \\
\text { HU6-24 } \\
\text { HU5-18 }\end{array}$ & $\begin{array}{l}0.1225 \\
0.3210^{a} \\
0.3956^{a}\end{array}$ & $\begin{array}{l}\text { HU1-15 } \\
\text { HU1-20 } \\
\text { GL7-03 }\end{array}$ & $\begin{array}{l}0.1542 \\
0.1332 \\
0.1554\end{array}$ \\
\hline $\mathrm{DC}$ & 1777 & $\begin{array}{l}119 \\
172 \\
145\end{array}$ & $\begin{array}{l}\text { HU5-24 } \\
\text { ILA-23 } \\
\text { GL7-14 }\end{array}$ & $\begin{array}{l}3.9865 \\
6.1143^{*} \\
4.0747\end{array}$ & $\begin{array}{l}\text { GL7-04 } \\
\text { GL7-1 } \\
\text { IU4-15 }\end{array}$ & $\begin{array}{l}0.2017 \\
0.2092 \\
0.1800\end{array}$ & $\begin{array}{l}\text { HU 1-15 } \\
\text { HU 1-20 } \\
\text { GL7-03 }\end{array}$ & $\begin{array}{l}0.1939 \\
0.1730 \\
0.1892\end{array}$ \\
\hline
\end{tabular}

aChipped stone. 
Table A.4. Weight changes (g) in exposed and control briquettes: fresh stone, quinquennials, 1989 runoff

\begin{tabular}{|c|c|c|c|c|c|c|c|c|}
\hline \multirow{2}{*}{$\begin{array}{l}\text { SAMPLE } \\
\text { AND } \\
\text { SITE }\end{array}$} & \multirow{2}{*}{$\begin{array}{l}\text { EXPOS. } \\
\text { TIME. } \\
\text { DAYS }\end{array}$} & \multirow[b]{2}{*}{ SLOT } & \multicolumn{2}{|c|}{ EXPOSED BRIQUETTES } & \multicolumn{2}{|c|}{ FIELD CONTROLS } & \multicolumn{2}{|c|}{ LAB CONTROLS } \\
\hline & & & $\begin{array}{c}\text { SAMPLE } \\
\text { NO. }\end{array}$ & $\begin{array}{l}\text { WEIGHT } \\
\text { CHANGE }\end{array}$ & $\begin{array}{c}\text { SAMPLE } \\
\text { NO. }\end{array}$ & $\begin{array}{l}\text { WEIGHT } \\
\text { CHANGE }\end{array}$ & $\begin{array}{c}\text { SAMPLE } \\
\text { NO. }\end{array}$ & $\begin{array}{l}\text { WEIGHT } \\
\text { CLLANGE }\end{array}$ \\
\hline \multicolumn{9}{|l|}{ Marble: } \\
\hline NY & 56 & $\begin{array}{l}219 \\
272 \\
245\end{array}$ & $\begin{array}{l}\text { A33-15 } \\
\text { A33-06 } \\
\text { I36-06 }\end{array}$ & $\begin{array}{l}0.0483 \\
0.0494 \\
0.0511\end{array}$ & $\begin{array}{l}114-03 \\
\text { K36-20 } \\
\text { G36-07 }\end{array}$ & $\begin{array}{r}-0.0024 \\
0.0033 \\
0.0047\end{array}$ & $\begin{array}{l}\mathrm{H} 14-18 \\
\text { G36-23 } \\
\text { G26-10 }\end{array}$ & $\begin{array}{l}-0.0043 \\
-0.0043 \\
-0.0036\end{array}$ \\
\hline $\mathrm{DC}$ & 113 & $\begin{array}{l}219 \\
272 \\
245\end{array}$ & $\begin{array}{l}\text { A33-19 } \\
\text { A33-03 } \\
136-10\end{array}$ & $\begin{array}{l}0.1013 \\
0.0916 \\
0.0939\end{array}$ & $\begin{array}{l}\text { H36-22 } \\
\text { K36-22 } \\
\text { G36-08 }\end{array}$ & $\begin{array}{l}0.0044 \\
0.0043 \\
0.0038\end{array}$ & $\begin{array}{l}\text { H14-18 } \\
\text { G36-23 } \\
\text { G26-10 }\end{array}$ & $\begin{array}{l}0.0037 \\
0.0049 \\
0.0096\end{array}$ \\
\hline \multicolumn{9}{|c|}{ Limestone: } \\
\hline NY & 56 & $\begin{array}{l}119 \\
172 \\
145\end{array}$ & $\begin{array}{l}\text { HU5-09 } \\
\text { IL4-11 } \\
\text { GL7-19 }\end{array}$ & $\begin{array}{l}0.0978 \\
0.0954 \\
0.0959\end{array}$ & $\begin{array}{l}\text { GUI-12 } \\
\text { HU6-24 } \\
\text { HU5-18 }\end{array}$ & $\begin{array}{l}0.0271 \\
0.0393^{a} \\
0.0415^{a}\end{array}$ & $\begin{array}{l}\text { HU 1-15 } \\
\text { HU } 1-20 \\
\text { GL7-03 }\end{array}$ & $\begin{array}{l}0.0269 \\
0.0270 \\
0.0213\end{array}$ \\
\hline $\mathrm{DC}$ & 113 & $\begin{array}{l}119 \\
172 \\
145\end{array}$ & $\begin{array}{l}\text { HU5-24 } \\
\text { ILA-23 } \\
\text { GL7-14 }\end{array}$ & $\begin{array}{l}0.3108 \\
0.9778^{\mathrm{a}} \\
0.8232^{\mathrm{a}}\end{array}$ & $\begin{array}{l}\text { GL7-04 } \\
\text { GL7-11 } \\
\text { IU4-15 }\end{array}$ & $\begin{array}{l}0.1038 \\
0.0997 \\
0.1017\end{array}$ & $\begin{array}{l}\mathrm{HU} 1-15 \\
\mathrm{HU} 1-20 \\
\text { GL7-03 }\end{array}$ & $\begin{array}{l}0.1106 \\
0.1056 \\
0.0991\end{array}$ \\
\hline
\end{tabular}

achipped stone. 
Table A.5. Weight changes $(g)$ in exposed and control briquettes: preexposed stone, annuals, 1988-1989

\begin{tabular}{|c|c|c|c|c|c|c|c|c|}
\hline \multirow{2}{*}{$\begin{array}{l}\text { SAMPLE } \\
\text { AND } \\
\text { SITE }\end{array}$} & \multirow{2}{*}{$\begin{array}{l}\text { EXPOS. } \\
\text { TIME. } \\
\text { DAYS }\end{array}$} & \multirow[b]{2}{*}{ SLOT } & \multicolumn{2}{|c|}{ EXPOSED BRIGUETTES } & \multicolumn{2}{|c|}{ FIELD CONTROLS } & \multicolumn{2}{|c|}{ LAB CONTROLS } \\
\hline & & & $\begin{array}{l}\text { SAMPLE } \\
\text { NO. }\end{array}$ & $\begin{array}{l}\text { WEIGHT } \\
\text { CHANGE }\end{array}$ & $\begin{array}{c}\text { SAMPLE } \\
\text { NO. }\end{array}$ & $\begin{array}{l}\text { WEIGHT } \\
\text { CHANGE }\end{array}$ & $\begin{array}{l}\text { SAMPLE } \\
\text { NO. }\end{array}$ & $\begin{array}{l}\text { WEIGHT } \\
\text { CHANGE }\end{array}$ \\
\hline \multicolumn{9}{|l|}{ Marble } \\
\hline $\mathrm{NC}$ & 348 & $\begin{array}{l}259 \\
251\end{array}$ & $\begin{array}{l}\text { W22-05 Up } \\
\text { W22-01 Dn }\end{array}$ & $\begin{array}{l}0.5140 \\
0.5125\end{array}$ & $\begin{array}{l}\text { G36-05 } \\
\text { H36-21 } \\
\text { I14-01 }\end{array}$ & $\begin{array}{l}0.0023 \\
0.0026 \\
0.0030\end{array}$ & $\begin{array}{l}\text { H14-18 } \\
\text { G36-23 } \\
\text { G26-10 }\end{array}$ & $\begin{array}{l}0.0044 \\
0.0018 \\
0.0017\end{array}$ \\
\hline NY & 378 & $\begin{array}{l}259 \\
251\end{array}$ & $\begin{array}{l}\text { W22-2 I Up } \\
\text { W22-03 Dn }\end{array}$ & $\begin{array}{l}0.5305 \\
0.5028\end{array}$ & $\begin{array}{l}114-03 \\
\text { K36-20 } \\
\text { G36-07 }\end{array}$ & $\begin{array}{r}0.0047 \\
-0.0053 \\
0.0198\end{array}$ & $\begin{array}{l}\text { H14-18 } \\
\text { G36-23 } \\
\text { G26-10 }\end{array}$ & $\begin{array}{l}0.0039 \\
0.0046 \\
0.0045\end{array}$ \\
\hline $\mathrm{DC}$ & 380 & $\begin{array}{l}259 \\
251\end{array}$ & $\begin{array}{l}\text { W22-23 Up } \\
\text { W22-12 Dn }\end{array}$ & $\begin{array}{l}0.6004 \\
0.6693\end{array}$ & $\begin{array}{l}\text { H36-22 } \\
\text { K36-22 } \\
\text { G36-08 }\end{array}$ & $\begin{array}{l}-0.0049 \\
-0.0049 \\
-0.0053\end{array}$ & $\begin{array}{l}\text { H14-18 } \\
\text { G36-23 } \\
\text { G26-10 }\end{array}$ & $\begin{array}{l}-0.0042 \\
-0.0064 \\
-0.0101\end{array}$ \\
\hline $\mathrm{OH}$ & 587 & $\begin{array}{l}258 \\
251\end{array}$ & $\begin{array}{l}\text { W22-24 Up } \\
\text { W22-17 Dn }\end{array}$ & $\begin{array}{l}1.0500 \\
1.1507\end{array}$ & $\begin{array}{l}\text { K15-13 } \\
\text { G22-03 } \\
\text { G34-12 }\end{array}$ & $\begin{array}{r}0.0003 \\
-0.0009 \\
0.0007\end{array}$ & $\begin{array}{l}\text { H14-18 } \\
\text { G36-23 } \\
\text { G26-10 }\end{array}$ & $\begin{array}{l}-0.0007 \\
-0.0015 \\
-0.0011\end{array}$ \\
\hline OHMS $^{\mathrm{a}}$ & 587 & 312 & W23-15 Up & 0.3902 & & & & \\
\hline \multicolumn{9}{|c|}{ Limestone } \\
\hline $\mathrm{NC}$ & 348 & $\begin{array}{l}159 \\
151\end{array}$ & $\begin{array}{l}\text { XW 1-06 Up } \\
\text { XW1-10 Dn }\end{array}$ & $\begin{array}{l}2.3051 \\
2.0766\end{array}$ & $\begin{array}{l}\text { HU6-01 } \\
\text { GU1-06 } \\
\text { HU4-24 }\end{array}$ & $\begin{array}{l}-0.0165 \\
-0.0147 \\
-0.0146\end{array}$ & $\begin{array}{l}\text { HU I- } 15 \\
\text { HUI-20 } \\
\text { GL7-03 }\end{array}$ & $\begin{array}{l}-0.0148 \\
-0.0178 \\
-0.0129\end{array}$ \\
\hline NY & 378 & $\begin{array}{l}159 \\
151\end{array}$ & $\begin{array}{l}\text { PW1-16 Up } \\
\text { XW1-04 Dn }\end{array}$ & $\begin{array}{l}2.6921 \\
3.1146\end{array}$ & $\begin{array}{l}\text { GU1-12 } \\
\text { HU6-24 } \\
\text { HU5-18 }\end{array}$ & $\begin{array}{l}0.0015 \\
0.2005^{b} \\
0.2845^{b}\end{array}$ & $\begin{array}{l}\text { HU 1-15 } \\
\text { HU1-20 } \\
\text { GL7-03 }\end{array}$ & $\begin{array}{r}0.0007 \\
-0.0020 \\
0.0036\end{array}$ \\
\hline $\mathrm{DC}$ & 380 & $\begin{array}{l}159 \\
151\end{array}$ & $\begin{array}{l}\text { PW 1-21 Up } \\
\text { PW 1-02 Dn }\end{array}$ & $\begin{array}{l}2.8042 \\
2.1281\end{array}$ & $\begin{array}{l}\text { GL7-04 } \\
\text { GL7-11 } \\
\text { IU4-15 }\end{array}$ & $\begin{array}{l}-0.0602 \\
-0.0575 \\
-0.0575\end{array}$ & $\begin{array}{l}\text { HU1-15 } \\
\text { HU1-20 } \\
\text { GL7-03 }\end{array}$ & $\begin{array}{l}-0.0587 \\
-0.0573 \\
-0.0537\end{array}$ \\
\hline $\mathrm{OH}$ & 587 & $\begin{array}{l}158 \\
151\end{array}$ & $\begin{array}{l}\text { PW 1-23 Up } \\
\text { PW1-01 Dn }\end{array}$ & $\begin{array}{l}3.3487 \\
3.2035\end{array}$ & $\begin{array}{l}\text { HL2-05 } \\
\text { IL8-02 } \\
\text { GL6-09 }\end{array}$ & $\begin{array}{l}-0.0764 \\
-0.0686 \\
-0.0765\end{array}$ & $\begin{array}{l}\text { HUl-15 } \\
\text { HU1-20 } \\
\text { GL7-03 }\end{array}$ & $\begin{array}{l}-0.0585 \\
-0.0598 \\
-0.054\end{array}$ \\
\hline OHMSa5 & 587 & 307 & PW1-22 Up & 0.6965 & - & - & - & - \\
\hline
\end{tabular}

aHMS - Ohio site movable rack - sprayed regime.

bChipped stone. 
Table A.6. Weight changes (g) in exposed and control briquettes: preexposed stone, annuals, 1989-1990 and 1990-1992

\begin{tabular}{|c|c|c|c|c|c|c|c|c|}
\hline \multirow{2}{*}{$\begin{array}{l}\text { SAMPLE } \\
\text { PERIOD. } \\
\text { SITE }\end{array}$} & \multirow{2}{*}{$\begin{array}{l}\text { EXPOS. } \\
\text { TIME. } \\
\text { DAYS }\end{array}$} & \multirow[b]{2}{*}{ SLOT } & \multicolumn{2}{|c|}{ EXPOSED BRIQUETTES } & \multicolumn{2}{|c|}{ FIELD CONTROLS } & \multicolumn{2}{|c|}{ LAB CONTROLS } \\
\hline & & & $\begin{array}{c}\text { SAMPLE } \\
\text { NO. }\end{array}$ & $\begin{array}{l}\text { WEIGHT } \\
\text { CHANGE }\end{array}$ & $\begin{array}{c}\text { SAMPLE } \\
\text { NO. }\end{array}$ & $\begin{array}{l}\text { WEIGITT } \\
\text { CHANGE }\end{array}$ & $\begin{array}{c}\text { SAMPLE } \\
\text { NO. }\end{array}$ & $\begin{array}{l}\text { WEIGHT } \\
\text { CHANGE }\end{array}$ \\
\hline Marble: & Period & $1989-$ & 990 & & & & & \\
\hline NY & 259 & $\begin{array}{l}259 \\
251\end{array}$ & $\begin{array}{l}\text { W22-21 Up } \\
\text { W22-03 Dn }\end{array}$ & $\begin{array}{l}0.4054 \\
0.4117^{a}\end{array}$ & $\begin{array}{l}\text { I } 14-03 \\
\text { K36-20 } \\
\text { G36-07 }\end{array}$ & $\begin{array}{r}-0.0032 \\
0.0018 \\
0.0041\end{array}$ & $\begin{array}{l}\text { H14-18 } \\
\text { G36-23 } \\
\text { G26-10 }\end{array}$ & $\begin{array}{l}-0.0042 \\
-0.0050 \\
-0.0047\end{array}$ \\
\hline $\mathrm{DC}$ & 385 & $\begin{array}{l}259 \\
251\end{array}$ & $\begin{array}{l}\text { W22-23 Up } \\
\text { W22-12 Dn }\end{array}$ & $\begin{array}{l}0.4129^{a} \\
0.4721\end{array}$ & $\begin{array}{l}\text { H36-22 } \\
\text { K36-22 } \\
\text { G36-08 }\end{array}$ & $\begin{array}{l}0.0008 \\
0.0021 \\
0.0002\end{array}$ & $\begin{array}{l}\mathrm{H} 14-18 \\
\text { G36-23 } \\
\text { G26-10 }\end{array}$ & $\begin{array}{l}0.0009 \\
0.0017 \\
0.0067\end{array}$ \\
\hline
\end{tabular}

Limestone: Period $1989-1990$

\begin{tabular}{|c|c|c|c|c|c|c|c|c|}
\hline \multirow[t]{3}{*}{$N Y$} & \multirow[t]{3}{*}{259} & 159 & PWl-16 Up & 0.9158 & GU1-12 & 0.0211 & HUI-15 & 0.0209 \\
\hline & & 151 & XWI-04 Dn & $2.1903^{a}$ & HU6-24 & 0.0345 & HUl-2O & 0.0203 \\
\hline & & & & & HU5-18 & 0.0357 & GL7-03 & 0.0163 \\
\hline \multirow[t]{2}{*}{ DC } & \multirow[t]{2}{*}{385} & 159 & PW1-21 Up & 0.4307 & GL7-04 & $0.1667^{b}$ & HU1-15 & 0.045 \\
\hline & & 151 & PW 1-02 Dn & $1.8992^{\mathrm{a}}$ & $\begin{array}{l}\text { GL7-11 } \\
\text { IU4-15 }\end{array}$ & $\begin{array}{l}0.0441 \\
0.0457\end{array}$ & $\begin{array}{l}\mathrm{HU} 1-20 \\
\mathrm{GL}-03\end{array}$ & $\begin{array}{l}0.0429 \\
0.0403\end{array}$ \\
\hline
\end{tabular}

Marble: Period $1990-1992$

NY

DC$$
642
$$$$
259
$$

W22-21 Up 0.5696

W22-03 Dn 0.5256

$114-03$

$\mathrm{K} 36-20$

G36-07

H36-22

K36-22

G36-08

W22-23 Up 0.2683

W22-12 Dn 0.1859

Limestone: Period $1990-1992$

NY$$
642
$$

159

PW 1-16 Up 0.6360

DC

283
XW I-04 Dn 0.8466

151

$$
\text { (xw }
$$

PW 1-2 1 Up 0.4282 PW1-02 Dn 0.4694
GU1-12

HU6-24

HU5-18

0.0264 $-0.0017$ 0.0293

GL7-04

GL7-11

IU4-15
$-0.0025$

$-0.0028$

$-0.0006^{b}$

0.0042

0.0013

0.0041
H14-18

G36 -23

G26-10

H14-18

G36-23

G26-10
$-0.0025$

$-0.0011$

$-0.0018$

0.0038

0.0036

0.0034 
Internal

H. Drucker

R. B. Poeppel

P. Hess

A. C. Raptis

C. A. Malefyt

K. J. Reimann (7)

S. A. Moll

J. Shannon

D. Streets

C. E. Till

R. A. Valentin

M. Wesely

TIS Files

\section{External}

DOE/OSTI, for distribution per UC-400 (25)

ANL Libraries

ANL-E

ANL-W

DOE-Chicago Field Office:

Manager

D. T. Goldman

F. Herbaty

A. L. Taboas

Energy Technology Division Review Committee:

H. K. Birnbaum, University of Illinois, Urbana

R. C. Buchanan. University of Cincinnati, Cincinnati, $\mathrm{OH}$

S. -N. Liu, Fremont, CA

H. S. Rosenbaum. Fremont, CA

R. K. Shah. University of Kentucky, Lexington

S. Smialowska, Ohio State University, Columbus

R. E. Smith, Altran Corp., Huntersville, NC

National Park Service:

M. Gilberg

L. Nelson

J. Rogers

S. Sherwood

M. Striegel (20)

United States Geological Survey:

P. Baedecker

M. Kingston

J. Morgan

V. Mossotti

R. Pickering

M. Reddy

E. Spiker

E. McGee

Colorado School of Mines:

D. Langmuir 